\title{
Virally-Mediated Versus Grazer-Induced Mortality Rates in a Warm-Temperate Inverse Estuary (Spencer Gulf, South Australia)
}

\author{
Laurent Seuront ${ }^{1,2 *}$, Mark Doubell ${ }^{3}$, Paul Van Ruth ${ }^{3}$ \\ ${ }^{1}$ CNRS, UMR 8187 LOG, Wimereux, France \\ ${ }^{2}$ School of Biological Sciences, Flinders University, Adelaide, Australia \\ ${ }^{3}$ Aquatic Sciences, South Australian Research and Development Institute, West Beach, Australia \\ Email: "laurent.seuront@univ-lille1.fr
}

Received 5 August 2014; revised 6 September 2014; accepted 18 September 2014

Copyright (C) 2014 by authors and Scientific Research Publishing Inc.

This work is licensed under the Creative Commons Attribution International License (CC BY). http://creativecommons.org/licenses/by/4.0/

c) (i) Open Access

\section{Abstract}

We investigated the seasonal dynamics of flow cytometrically-defined populations of viruses, heterotrophic bacteria, and the picoeukaryotic and prokaryotic phytoplankton at three sites in the temperate oligotrophic inverse estuary of Spencer Gulf (South Australia). We consistently identified two sub-populations of viruses, three sub-populations of heterotrophic bacteria, one population of picoeukaryotic phytoplankton and two populations of prokaryotic phytoplankton (cyanobacteria Prochlorococcus and Synechococcus). Both the cytometric community composition and the abundance of viruses, heterotrophic bacteria and both prokaryotic (Synechococcus and Prochlorococcus) and eukaryotic picophytoplankton were consistent with previous observations conducted in South Australian continental shelf waters. Noticeably LDNA bacteria (i.e. inactive or dormant cells) were consistently significantly the most abundant group of heterotrophic bacteria (totaling from $29 \%$ to $68 \%$ of total bacterial abundance) and were up to 10 -fold more abundant than that previously reported in South Australian continental shelf waters, including the nearby Saint Vincent Gulf. These results suggest an overall low activity of the microbial community, and are consistent with previous evidence that LDNA cells may play a greater role in heterotrophic processes than HDNA cells in oligotrophic waters. In an attempt to further assess the qualitative and quantitative nature of the mortality of these organisms, we used a specific dilution assay to assess the relative contribution of viruses and microzooplankton grazers to the mortality rates of heterotrophic bacteria, and picoeukaryotic and prokaryotic phytoplankton. We consistently reported site-specific, population specific and sea-son-specific viral lysis and grazing rates of heterotrophic bacteria and the picoeukaryotic and prokaryotic (cyanobacteria Prochlorococcus and

\footnotetext{
Corresponding author.
}

How to cite this paper: Seuront, L., Doubell, M. and Van Ruth, P. (2014) Virally-Mediated Versus Grazer-Induced Mortality Rates in a Warm-Temperate Inverse Estuary (Spencer Gulf, South Australia). Open Journal of Marine Science, 4, $257-278$. 
Synechococcus) phytoplankton across sites and seasons. Specifically, both viral lysis and mi-crozooplankton grazing rates of heterotrophic bacteria were consistently relatively low across sites and seasons, even though their seasonality suggested an overall dominance of grazing over viral lysis in both summer and winter. In contrast, no seasonality is found in either lysis or grazing rates of prokaryotic and eukaryotic picophytoplankton, which are comparable to previous observations conducted in oligotrophic waters, suggesting the mortality dynamics of these populations is similar to those en-countered in other oligotrophic waters. The observed patterns of mortality rates of heterotrophic bacteria and both prokaryotic and eukaryotic picophytoplankton are consistent with the low chlorophyll concentration and production previously observed in the waters of the Spencer Gulf.

\section{Keywords}

Lysis, Grazing, Bacteria, Viruses, Prokaryotic and Eukaryotic Picophytoplankton, Dilution Assay

\section{Introduction}

Viruses are ubiquitous in the world ocean, and by far the most abundant (typically in the range $10^{5}$ to $10^{8} \mathrm{ml}^{-1}$ ) biotic agent [1]-[3]. Viruses play a critical role in marine biogeochemical cycling through their role in the transformation of host cells into bio-available dissolved organic matter, hence the diversion of carbon away from the classical food web toward microbially-mediated recycling processes [1]-[4]; they are estimated to be responsible for $c a .10^{29}$ infections per day, which ultimately lead to the release of $10^{8}$ to $10^{9}$ tons of carbon per day from the biological pool [3]. Beyond the ongoing biogeochemical debate whether viruses 1) short-circuit the biological pump by releasing elements back to the dissolved phase [5]; 2) prime the biological pump by accelerating host export from the euphotic zone [6]; or 3) drive particle aggregation and transfer of car-bon into the deep sea through the release of sticky colloidal cellular components during viral lysis [7]. There is also compelling evidence that viral activity potentially affect population dynamics, community structure, diversity and genetic transfer [8] [9]. Viral activity is also expected to increase net community respiration (hence to decrease the production/respiration ratio), and accelerates the recycling of potentially growth-limiting nutrients [10]. Viruses may hence potentially either hinder or stimulate biological production, which is an issue of global significance, especially in oligotrophic waters.

The role of viral lysis is acknowledged in the mortality of marine bacteria and phytoplankton [2] [3] [11]-[13]. The study of relative contributions of viral lysis and microzooplankton grazing to bacteria and phytoplankton mortalities is, however, still overlooked [3] [14]-[16]. In contrast, there is a plethora of literature solely devoted to microzooplankton grazing in a range of environments; see [17]-[19] for re-views. As viral lysis may account for $2 \%$ to $77 \%$ of bacterial mortality in the ocean [1] [8] [9], a thorough assessment of the relative contribution of microzooplankton grazing and virally-mediated mortality is critically needed to improve our understanding of the transfer pathways of organic matter throughout marine ecosystems. Both microzooplankton grazing and viral lysis regenerate nutrients. However, there are fundamental differences in 1) the resulting physical (size classes of organic material) and chemical (organic vs. inorganic) speciation of released materials; and 2) the redistribution of nutrients to more organic species through viral lysis relative to the inorganic forms excreted by grazers that may respectively regulate community diversity and productivity and shift the competitive equilibrium for growth-limiting nutrients between phytoplankton and bacteria [1]-[3] [10].

A specific assay that allows a direct estimation of the relative contribution of virus-induced and grazer-induced algal mortality has been successfully applied for the picophytoplankter Micromonas pusilla during a mesocosm study [20], to the nanophytoplankter Phaeocystis globosa during a field study in temperate eutrophic coastal waters [14] and in oligotrophic waters of the open ocean to different groups of prokaryotes and eukaryotes in the subtropical northeastern Atlantic [15] and to the phytoplankton $<200 \mu \mathrm{m}$ in the Southern Ocean southeast of the Kerguelen [16]. To our knowledge, this dilution assay has, as yet, never been applied to assess the mortality rates of both heterotrophic bacteria and the eukaryotic and prokaryotic components of the picophytoplankton community. In particular, beyond the general paucity of information available in the literature, no study has yet focused on the microbial dynamics of inverse estuaries, known to seasonally alternate between 
oligotrophic and mesotrophic/eutrophic conditions; see e.g. [21]. In this context, the present work investigates the nature of the viral, microbial and picophytoplanktonic communities of the Spencer Gulf, a South Australian warm-temperate inverse estuary considered oligotrophic due to the paucity of both riverine and terrigenous inputs and precipitation, and characterized by a relatively low primary productivity [22]-[24] that is unique at times phosphorus-limited [25], and subsequently low secondary productivity that does not exert a control on the phytoplankton community [22]-[25]. These results suggest a bottom-up control of the matter cycling in the Spencer Gulf, hence we stress the need to thoroughly assess the structure and function of the microbial food web in these waters.

Specifically, the objectives of the present work were 1) to assess the nature of the viral, microbial and picophytoplanktonic communities; and 2) to elucidate the relative contributions of virally-induced mortality and microzooplankton grazing in heterotrophic bacteria, and the picoeukaryotic and prokaryotic (cyanobacteria Prochlorococcus and Synechococcus) phytoplankton at three sites representative of the hydrographic conditions encountered from the oceanic mouth to the inland head of the Spencer Gulf (South Australia), in spring, summer, autumn and winter.

\section{Materials and Methods}

\subsection{Study Site}

Spencer Gulf is the largest marine embayment along the southern Australian coastline (Figure 1). It extends northwards ca. $320 \mathrm{~km}$ and is $130 \mathrm{~km}$ wide at its mouth, with an average width of $60 \mathrm{~km}$ (Figure 1). The coastal

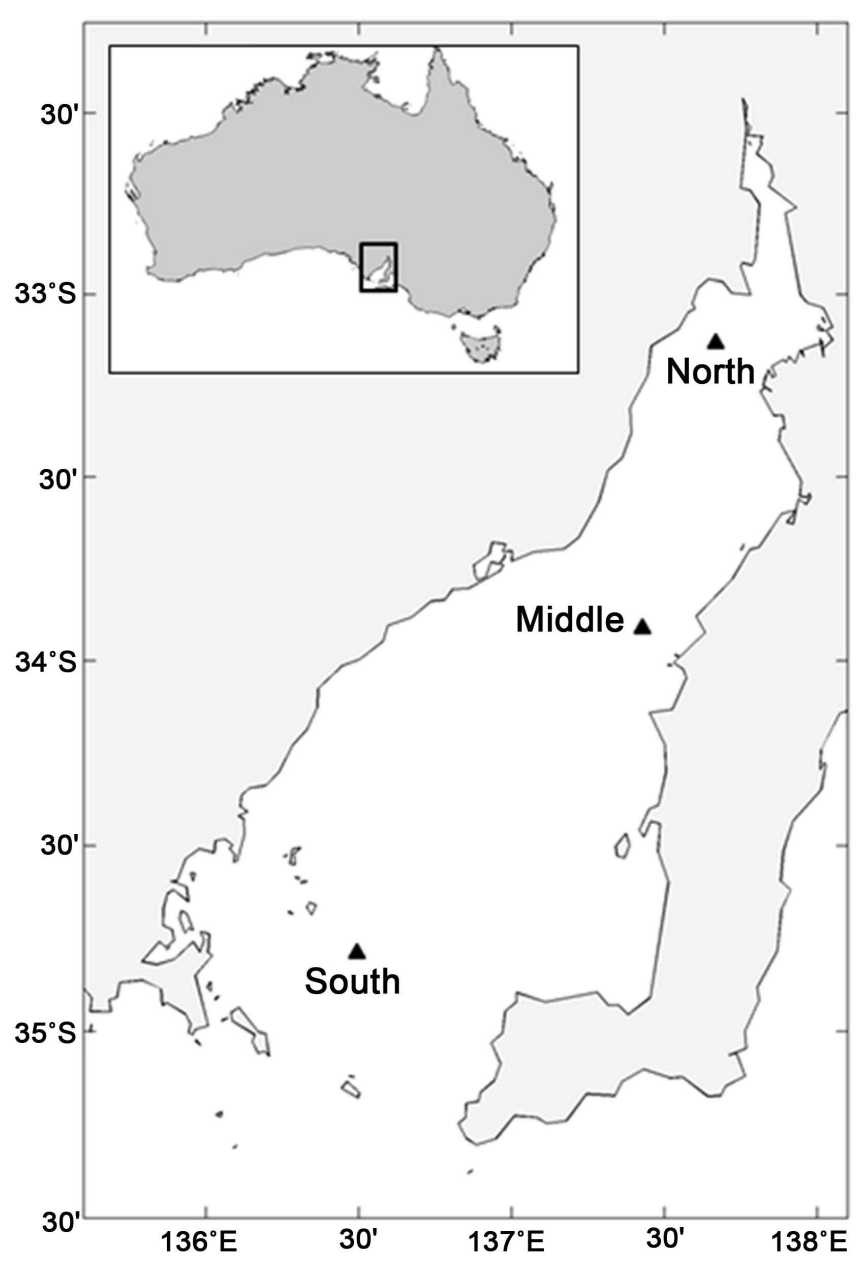

Figure 1. Study area and sampling sites within Spencer Gulf, South Australia. 
geometry affords some shelter from predominantly southwest ocean-generated swell [26]-[28]. No permanent rivers bring freshwater or terrigenous sediments into the Gulf, and the semi-arid (annual rainfall typically $<550$ mm) [26] [29] warm-temperate climate results in seasonal heating and high evaporation. Salinity hence ranges from oceanic salinity at the Gulf mouth up to $c a$. 50 PSU at the inland head in late summer, leading to a pattern of inverse estuarine circulation with low productivity and little seasonal variation [30]-[32]. Specifically, this circulation pattern is imposed on an overall internal clockwise gyral circulation that brings marine waters into the Gulf from the west. These waters are modified therein and exit the Gulf in the east as a mesotrophic saline outflow. Whilst the gulf experiences outflow throughout the year, this outflow is enhanced during autumn and winter seasons as salty waters formed in northern regions of the gulf are cooled forming a gravity current, which exists the gulf along its eastern flank [33] [34]. With an average water depth of $c a .24 \mathrm{~m}$ (maximum depth is only $60 \mathrm{~m}$ ), tidal current velocities within the gulf range between 0.5 to $1.5 \mathrm{~m} \cdot \mathrm{s}^{-1}$ [35] and are large relative to the velocities of $c a$. 0.1 to $0.2 \mathrm{~m} \cdot \mathrm{s}^{-1}$ generated by gravity currents [33] and wind [36]. As a consequence, the vertical structure of the water column is generally well mixed. The interface between Spencer Gulf and shelf water creates a front in summer [37] [38] where larval fish have been shown to aggregate [39], possibly as a result of convergent flows [40].

The Spencer Gulf is characterized by a variety of habitats including mangroves, saltmarshes and seagrass beds, tidal flats, dune systems, pebble beach ridges and submerged "sand waves" and reef systems [41]. It supports, as most of the southern Australian coast, a uniquely high degree of endemism and high floristic and faunistic diversity [42]-[44], and is home of iconic species such as the Giant Australian Cuttlefish [45] [46], Great White Sharks [47], Leafy and Weedy seadragons [48] [49], a variety of marine birds and mammals [50], and a relic population of Tiger Pipefish [51]. The Spencer Gulf is also an active area for an aquaculture industry that is worth \$242 M for 2011/12 [52]. Key aquaculture species include southern Bluefin tuna, yellowtail kingfish, abalone and oysters. Despite the observed diversity and sustained fisheries and aquaculture activities, very limited information are still available on the structure and function of the planktonic ecosystem in Spencer Gulf waters that are generally considered oligotrophic, with 1) phytoplankton biomass consistently lower than $0.5 \mu \mathrm{g} \cdot l^{-1}$ across the Gulf, concentrations that are comparable to levels reported for oligotrophic waters off western and south eastern Australia (0.1-0.7 $\left.\mu \mathrm{g} \cdot \mathrm{l}^{-1}\right)$ [53]-[55] and offshore waters of the eastern and central Great Australian Bight ( $<0.1-0.4 \mu \mathrm{g} \cdot \mathrm{l}^{-1}$ ) [56]; 2) relatively low primary productivity uniquely phosphorus-limited [25]; and 3) a subsequently low secondary productivity that is not considered strong enough for the mesozooplankton to exert a top-down control of phytoplankton community [25]. No information is yet available on the nature, abundance and diversity of the viral, microbial and picophytoplanktonic communities of the Spencer Gulf.

\subsection{Sampling Sites and Sampling Strategy}

Water samples were collected from three locations with-in Spencer Gulf using the FV Atlas during four (seasonal) surveys of the gulf on November 16-18, 2010 (Spring), February 16-18, 2011 (Summer), 17-19 April, 2011 (Autumn) and 14-16 August, 2011 (Winter). Site locations were based the spatial regions defined by Nunes-Vaz [57], with one site sampled in the southern (South; $34^{\circ} 47^{\prime} \mathrm{S}, 136^{\circ} 29^{\prime} \mathrm{E}$ ), middle (Middle; $34^{\circ} 54^{\prime} \mathrm{S}$, $137^{\circ} 25^{\prime} \mathrm{E}$ ) and northern (North; $33^{\circ} 08^{\prime} \mathrm{S}, 137^{\circ} 40^{\prime} \mathrm{E}$ ) basins of the gulf, respectively (Figure 1). At each site, two surface water samples were taken using a $30 \mathrm{~L}$ Niskin bottle before being transferred immediately for storage into 25 liter acid-washed $(0.1 \mathrm{~N} \mathrm{HCl})$ polyurethane carboy's.

Water samples were then prepared for flow cytometric picophytoplankton, bacterial and viral enumeration and identification (see Sections 2.3 and 2.4) and micro-zooplankton grazing and viral lysis dilution assay experiments (see Section 2.4). Triplicate samples (1 ml) for flow cytometry were fixed 1 ) with glutaraldehyde (0.5\% final concentration) and incubated for $15 \mathrm{~min}$ at $4^{\circ} \mathrm{C}$ [58] for viruses and heterotrophic bacteria identification and enumeration; and 2) with paraformaldehyde (2\% final concentration) for picophytoplankton identification and enumeration. All samples were subsequently quick frozen in liquid nitrogen, stored at $-80^{\circ} \mathrm{C}$ once re-turned to the laboratory and analyzed by flow cytometry (FCM) using a FAC Scanto flow cytometer (Becton Dickinson) within a month of collection.

Additional water samples were collected for determining macro-nutrient and chlorophyll $a$ concentrations. For macro-nutrients analysis $100 \mathrm{ml}$ was filtered through a $0.45 \mu \mathrm{m}$ filter then frozen and stored at $-22^{\circ} \mathrm{C}$ prior to laboratory analysis. Dissolved ammonium (NH3, APHA-AWWA-WPCF 1998a, detection limit $0.071 \mu \mathrm{M}$ ), oxides of nitrogen $\left(\mathrm{NO}_{x}\right.$, APHA-AWWA-WPCF 1998b, detection limit $\left.0.071 \mu \mathrm{M}\right)$, phosphate $\left(\mathrm{PO}_{4} \mathrm{APHA}-\right.$ 
AWWA-WPCF 1998c, detection limit $0.032 \mu \mathrm{M})$ and silicate $\left(\mathrm{SiO}_{2}\right.$, APHA-AWWA-WPCF 1998d, detection limit $0.333 \mu \mathrm{M}$ ), were determined by flow injection analysis with a QuickChem 8500 Automated Ion Analyzer. The pigment composition of water samples was measured using High Pressure Liquid Chromatography (HPLC). Two liter water samples were filtered through Whatman GF/F filters (nominal pore size $0.4 \mu \mathrm{m}$ ) which were snap-frozen in liquid nitrogen and stored at $-80^{\circ} \mathrm{C}$ prior to analysis via the gradient elution procedure [58] on an Algilent 1200 series HPLC system in the environmental chemistry laboratory at SARDI Aquatic Sciences. Vertical profiles of temperature and salinity were measured using a Seabird SBE 19-plus conductivity, temperature and depth recorder (CTD) at each site prior to water sampling.

\subsection{Viral and Bacterial Identification and Enumeration}

Prior to FCM analysis, samples were quick thawed and diluted 1:10 with $0.2 \mathrm{~mm}$ filtered TE buffer (10 mM Tris, $1 \mathrm{mM}$ EDTA), stained with SYBR-I Green solution (1:500 dilution; Molecular Probes) and finally incubated in the dark at $80^{\circ} \mathrm{C}$ for $10 \mathrm{~min}$ [58]. Fluorescent beads with a diameter of $1 \mathrm{~mm}$ (Molecular Probes) were added to each sample as an internal size and concentration standard at a final concentration of approximately $10^{5}$ beads $\mathrm{ml}^{-1}$ [59]. Phosphate-buffered saline (PBS) solution was used as sheath fluid, while forward-angle light scatter (FSC), side-angle light scatter (SSC) and green (SYBR-I) fluorescence were recorded for each sample. Data for each sample were collected in list-mode files and analyzed using Win MDI 2.8 software ${ }^{\odot}$ Joseph Trotter).

Viral and heterotrophic bacterial populations were discriminated based on their differences in cell side scatter, a proxy of cell size, and SYBR Green fluorescence, which indicates the amount of nucleic acid present in each cell [59]-[61]. Bacterial populations were then split into two high DNA (HDNA1 and HDNA2) and one low DNA (LDNA) groups using the differences in green fluorescence [62] [63]. Viral populations were split into two virus-like particle populations (VLP1 and VLP2) based on their differences in green fluorescence and SSC (Figure 2(a)). More specifically, VLP1 and VLP2 corresponded to populations widely observed in seawater samples and identified as bacteriophages e.g. [61] [64]-[67].

\subsection{Picophytoplankton Identification and Enumeration}

Prior to FCM analysis, samples were quick thawed and $1 \mathrm{~mm}$ fluorescent marker beads (Molecular Probes, Eugene, OR, USA) added [61]. Each sample was run for $5 \mathrm{~min}$, and natural orange fluorescence from phycoerythrin and red fluorescence from chlorophyll, together with forward light scatter and side light scatter (SSC), were recorded. All cytograms were then analyzed using Win MDI 2.8 software $\left({ }^{\odot}\right.$ Joseph Trotter) following [61].

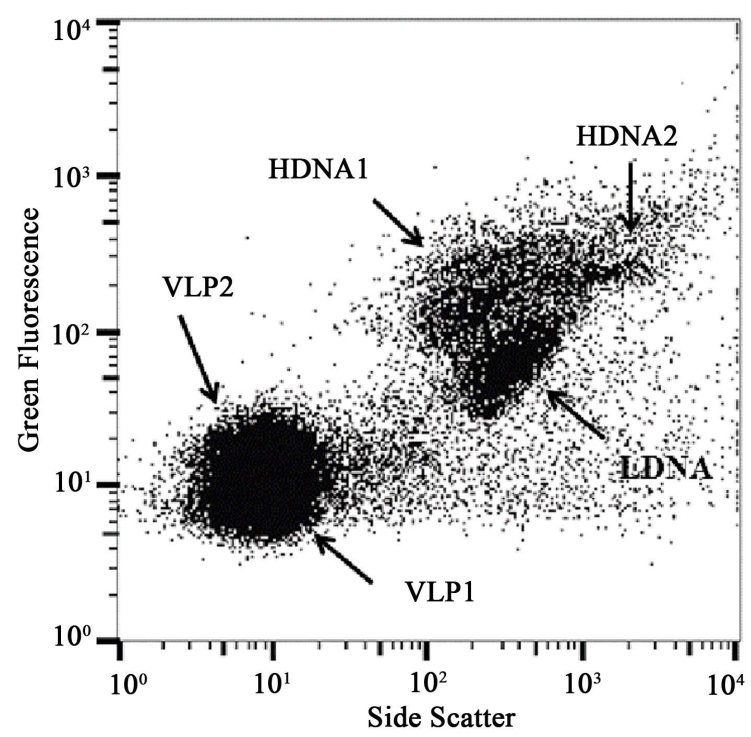

(a)

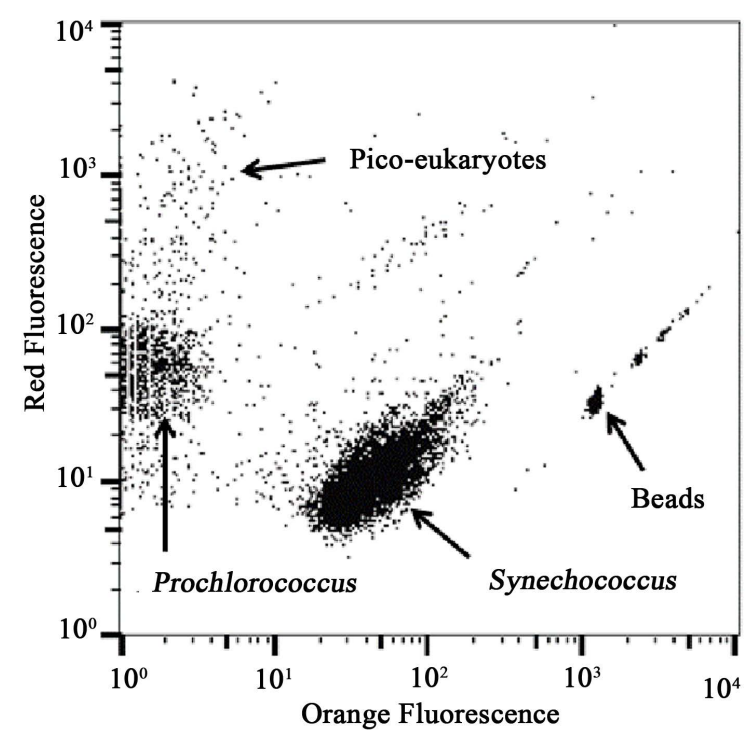

(b)

Figure 2. Representative cytograms used to determine viral and bacterial ((a): autumn, Southern site) and pico-phytoplankton ((b): summer, Northern site) abundance. 
One population of picoeukaryotic phytoplankton and two populations of prokaryotic phytoplankton (cyanobacteria Prochlorococcus and Synechococcus) were then discriminated based on their distinct autofluorescence and light scatter properties (Figure 2(b)). Specifically, Synechococcus and Prochlorococcus mainly differed by their orange fluorescence (Figure 2(b)), while picoeukaryotes were identified by their distinct red fluorescence (Figure 2(b)).

\subsection{Dilution Assay}

This experiment aimed at assessing the mortality rates of heterotrophic bacteria and both eukaryotic and prokaryotic picophytoplankton due to microzooplankton grazing and viral lysis. Mortality rates due to grazing $\left(M_{g}\right)$ and viral lysis $\left(M_{v}\right)$ were estimated following [20]. Specifically, seawater was collected from each site with 25 liter acid-washed $(0.1 \mathrm{~N} \mathrm{HCl})$ polyurethane carboy, and first mesozooplankton were removed by gravity siphoning the sample water through a $200 \mu \mathrm{m}$ mesh filter. Two dilution series were subsequently prepared, using grazer-free and virus-free diluent fractions. The grazer-free diluent fraction was prepared by vacuum filtration through a $0.2 \mu \mathrm{m}$ filter (Pall Corporation). The virus-free water fraction was prepared by filtering grazer-free diluent through a $30 \mathrm{kDa}$ tangential flow filtration system (Millipore). Diluents were then siphoned into acid washed $(0.1 \mathrm{~N} \mathrm{HCl}) 2 \mathrm{~L}$ Nalgene bottles (Schott) to create 4 dilutions of natural seawater $(20 \%, 40 \%, 70 \%$ and $100 \%$ ). These bottles were subsequently filled to capacity with freshly collected $200 \mu \mathrm{m}$ filtered natural site water, i.e. a $20 \%$ natural water dilution was comprised of $20 \% 200 \mu \mathrm{m}$ filtered site water and $80 \%$ diluent while a $100 \%$ natural water dilution contained only $200 \mu \mathrm{m}$ filtered natural site water. For each dilution bottle, $250 \mathrm{ml}$ was siphoned into triplicate acid washed $(0.1 \mathrm{~N} \mathrm{HCl}) 250 \mathrm{ml}$ glass incubation bottles (Schott) and triplicate samples were taken from each bottle for enumeration of heterotrophic bacteria and eukaryotic and prokaryotic picophytoplankton ( $t=0 \mathrm{~h}, t_{0}$ ). These bottles were then refilled to $250 \mathrm{ml}$ with previously diluted water. The incubation bottles were sealed using Parafilm ${ }^{\circledR}$ M (Pechiney Plastic Packaging Company) and incubated for 24 hours in a $4000 \mathrm{l}$ holding tank containing seawater on site. After 24 hours $\left(t=24 \mathrm{~h}, t_{24}\right)$, triplicate samples were taken from each incubation bottle for flow cytometric enumeration of heterotrophic bacteria and eukaryotic and prokaryotic (Synechococcus, Prochlorococcus) picophytoplankton.

\subsection{Statistical Analysis}

Due to the low number of data points available, non-parametric statistics were used throughout this work. Specifically, multiple comparisons between sites and seasons were conducted using the Kruskal-Wallis test (KW test hereafter), and a subsequent multiple comparison procedure based on the Tukey test was used to identify distinct groups of measurements.

\section{Results}

\subsection{Environmental Conditions}

Samples were collected months that are representative of the Austral seasons and water temperatures and salinities measured by the CTD were consistent with seasonal oscillations and the inverse estuarine circulation of the Gulf (Table 1). Near surface water temperatures showed the greatest variability, ranging from $13.7^{\circ} \mathrm{C}$ to $23.9^{\circ} \mathrm{C}$, at the northern site. Water temperatures adjacent to shelf at the southern site showed reduced seasonal variability and ranged between $15.3^{\circ} \mathrm{C}$ to $21.5^{\circ} \mathrm{C}$. With the exception of winter, surface waters generally increased in temperature northwards along the gulf. Salinity showed a similar pattern to temperature and increased from south to north across the seasons. Salinity minimum and maximum values ranged from 35.9 PSU at the southern site in winter to a maximum of 39.6 PSU at the northern site in autumn.

The concentrations of macro-nutrients were typically low, with phosphate and nitrate concentrations typically below the detection limit $(<0.032 \mu \mathrm{M}$; Table 1$)$ for each site and season, with exception for winter at the southern site where both the concentration of phosphate $\left(\mathrm{PO}_{4}=0.035 \mu \mathrm{M}\right)$ and nitrate $\left(\mathrm{NO}_{\mathrm{x}}=0.33 \mu \mathrm{M}\right)$ peaked. Silica concentrations were measured above the detection limit for all sites and seasons and generally increased in concentration from the south to the north across the seasons. Similarly, chlorophyll $a$ concentrations generally increased from the south to the north across the seasons with the majority of the phytoplankton biomass dominated by the small $(<5 \mu \mathrm{m})$ size fraction. 
Table 1. Seasonal abiotic and biotic properties of surface waters at sampling locations within Spencer Gulf. bd: below detection limit.

\begin{tabular}{|c|c|c|c|c|}
\hline Northern site & Spring & Summer & Autumn & Winter \\
\hline Bottom depth (m) & 15 & 15 & 15 & 15 \\
\hline Temperature $\left({ }^{\circ} \mathrm{C}\right)$ & 19.1 & 23.9 & 19.2 & 13.7 \\
\hline Salinity (PSU) & 38.5 & 39.4 & 39.6 & 39.4 \\
\hline Chl. $a\left(>5 \mu \mathrm{m} ; \mathrm{mg} \cdot \mathrm{m}^{-3}\right)$ & 0.08 & 0.12 & 0.07 & 0.05 \\
\hline Chl. $a\left(<5 \mu \mathrm{m} ; \mathrm{mg} \cdot \mathrm{m}^{-3}\right)$ & 0.20 & 0.52 & 0.27 & 0.27 \\
\hline $\mathrm{NO}_{\mathrm{x}}(\mu \mathrm{M})$ & bd & 0.16 & bd & bd \\
\hline $\mathrm{NH}_{3}(\mu \mathrm{M})$ & bd & 0.13 & 0.27 & bd \\
\hline $\mathrm{PO}_{4}(\mu \mathrm{M})$ & bd & bd & bd & bd \\
\hline $\mathrm{SiO}_{2}(\mu \mathrm{M})$ & 1.32 & 1.25 & 1.04 & 0.66 \\
\hline Middle site & Spring & Summer & Autumn & Winter \\
\hline Bottom depth (m) & 25 & 25 & 25 & 25 \\
\hline Temperature $\left({ }^{\circ} \mathrm{C}\right)$ & 18.1 & 23.2 & 18.6 & 13.8 \\
\hline Salinity (PSU) & 37.7 & 38.5 & 37.9 & 37.9 \\
\hline Chl. $a\left(>5 \mu \mathrm{m} ; \mathrm{mg} \cdot \mathrm{m}^{-3}\right)$ & 0.03 & 0.04 & 0.07 & 0.03 \\
\hline Chl. $a\left(<5 \mu \mathrm{m} ; \mathrm{mg} \cdot \mathrm{m}^{-3}\right)$ & 0.18 & 0.27 & 0.39 & 0.19 \\
\hline $\mathrm{NO}_{\mathrm{x}}(\mu \mathrm{M})$ & bd & 0.08 & bd & 0.28 \\
\hline $\mathrm{NH}_{3}(\mu \mathrm{M})$ & 0.35 & 0.14 & 0.23 & 0.14 \\
\hline $\mathrm{PO}_{4}(\mu \mathrm{M})$ & bd & bd & bd & bd \\
\hline $\mathrm{SiO}_{2}(\mu \mathrm{M})$ & 0.45 & 1.07 & 0.46 & 1.12 \\
\hline Southern site & Spring & Summer & Autumn & Winter \\
\hline Bottom depth (m) & 45 & 45 & 45 & 45 \\
\hline Temperature $\left({ }^{\circ} \mathrm{C}\right)$ & 16.5 & 21.5 & 18.6 & 15.3 \\
\hline Salinity (PSU) & 36.2 & 36.8 & 36.8 & 35.9 \\
\hline Chl. $a\left(>5 \mu \mathrm{m} ; \mathrm{mg} \cdot \mathrm{m}^{-3}\right)$ & 0.03 & 0.02 & 0.05 & 0.03 \\
\hline Chl. $a\left(<5 \mu \mathrm{m} ; \mathrm{mg} \cdot \mathrm{m}^{-3}\right)$ & 0.15 & 0.19 & 0.35 & 0.13 \\
\hline $\mathrm{NO}_{x}(\mu \mathrm{M})$ & bd & bd & bd & bd \\
\hline $\mathrm{NH}_{3}(\mu \mathrm{M})$ & 0.11 & bd & 0.20 & bd \\
\hline $\mathrm{PO}_{4}(\mu \mathrm{M})$ & bd & bd & bd & 0.03 \\
\hline $\mathrm{SiO}_{2}(\mu \mathrm{M})$ & 0.59 & 0.59 & 0.44 & 0.72 \\
\hline
\end{tabular}

\subsection{Viral and Bacterial Abundance}

Two viral (VLP1, VLP2) and three bacterial (LDNA, HDNA1, HDNA2) sub-populations were consistently observed at all sites over the four seasons (Figure 2(a)). Total viral abundance ranged from $3.04 \times 10^{5}$ to $5.26 \times$ $10^{6} \mathrm{ml}^{-1}$, while total bacterial abundance ranged from $3.18 \times 10^{5}$ to $2.58 \times 10^{6}$ cells $\cdot \mathrm{ml}^{-1}$. Total viral and bacterial abundances were significantly positively correlated $(p<0.05)$, and both exhibit significant spatial and temporal patterns of variability (KW test, $p<0.05$; Figure 3, Table 1). Specifically, both viral and bacterial abundances significantly differed $(p<0.05)$ between sites for each season, and show an increasing trend from the 

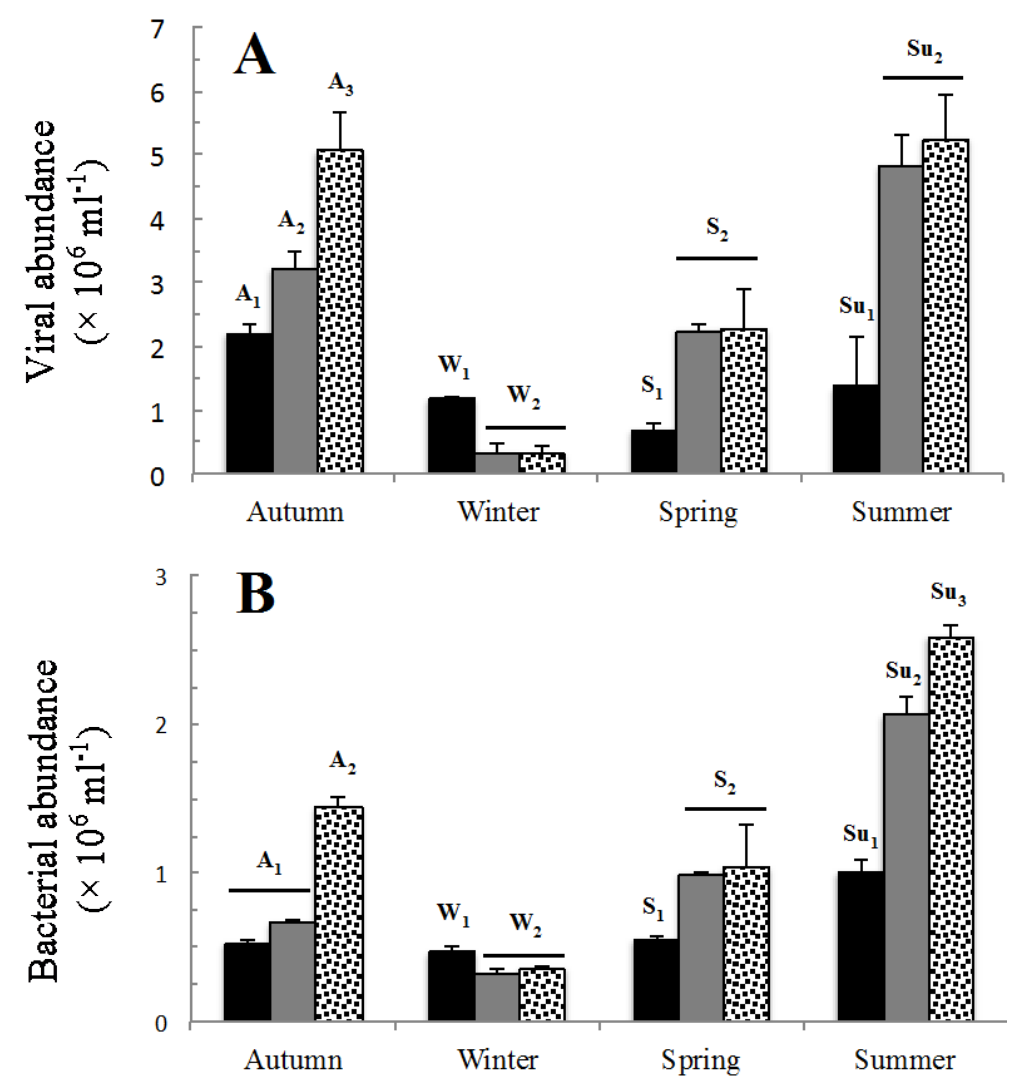

Figure 3. Total viral (A) and bacterial (B) abundance at the Southern (black bars), Middle (grey bars) and Northern (dotted bars) sites in autumn, winter, spring and summer. The letters " $\mathrm{A}_{\mathrm{i}}$ ", " $\mathrm{W}_{\mathrm{i}}$ ", " $\mathrm{S}_{\mathrm{i}}$ " and " $\mathrm{Su}_{\mathrm{i}}$ " identify significant differences $(p<0.05)$ inferred for each season using the Kruskal-Wallis test, and a subsequent multiple comparison procedure based on the Tukey test. Error bars are standard deviations.

southern site to the Northern site in autumn, spring and summer. In winter, significantly higher viral and bacterial abundances were, however, observed at the Southern site. Site-specific significant differences were also observed seasonally in viral and bacterial abundances with a general trend towards lower abundances in spring and winter and higher abundances in summer and autumn (Table 2).

VLP1 (Figure 4(a)) was by far the most abundant viral sub-population at all sites, especially in winter, spring and summer where it was respectively from 18 to 56-fold, 4 to 133 -fold and 57 to 200 -fold more abundant than VLP2 (Figure 4(b)). In autumn, VLP1 was only 1.2 to 2.4-fold more abundant than VLP2. VLP1 hence accounted for $94.7 \%$ to $98.2 \%$ of VLP in winter, $80.5 \%$ to $99.3 \%$ in spring, $98.3 \%$ to $99.5 \%$ in summer, and was nearly as abundant as VLP2 in autumn, especially at the middle and Northern sites where they represented 54\% to $58 \%$ of VLP against nearly $70 \%$ at the Northern site. In contrast, VLP2 were significantly more abundant in autumn at all sites, reaching concentrations on average 7, 32 and 80-fold higher than in spring, summer, and winter (Figure 4(b)). VLP1 and VLP2 abundances were both highly significantly positively correlated $(p<0.01)$ to total virus abundances, but only VLP1 abundance correlated significantly with bacterial abundance $(p<0.05)$. VLP1 and VLP2 temporal patterns are overall similar to those reported for total viral and bacterial abundance (Table 2).

The abundance of LDNA, HDNA1 and HDNA2 sub-populations significantly differed between sites for each season $(p<0.05$ ), and was consistently significantly higher in summer at the Northern site (Figure 5). LDNA was significantly more abundant at all sites for all seasons, except in summer at the Southern site. Specifically, the relative contribution of LDNA to total bacteria abundance ranged from $38.9 \%$ to $53.9 \%$ in spring, $47.3 \%$ to $52.0 \%$ in autumn, and $44.8 \%$ to $68.4 \%$ in winter, but only from $28.7 \%$ to $41.0 \%$ in summer. Both total viral and bacterial abundances were highly significantly positively correlated with LDNA, HDNA1 and HDNA2 abun- 
Table 2. Results of the multiple comparisons conducted on the abundance of viral and bacterial subpopulations and both picoeukaryoteic (Prochlorococcus and Synechococcus) and prokaryotic phytoplankton using the Kruskal-Wallis test, and a subsequent multiple comparison procedure based on the Tukey test when the null hypothesis was rejected.

\begin{tabular}{|c|c|c|c|c|c|c|c|}
\hline Northern site & & & & & & & \\
\hline VLP & Winter & $<$ & Spring & $<$ & Autumn & $=$ & Summer \\
\hline VLP1 & Winter & $<$ & Spring & $<$ & Autumn & $=$ & Summer \\
\hline VLP2 & Winter & $<$ & Summer & $<$ & Spring & $<$ & Autumn \\
\hline Bacteria & Winter & $<$ & Spring & $<$ & Autumn & $<$ & Summer \\
\hline LDNA & Winter & $<$ & Spring & $<$ & Autumn & $<$ & Summer \\
\hline HDNA1 & Winter & $<$ & Spring & $=$ & Autumn & $<$ & Summer \\
\hline HDNA2 & Winter & $<$ & Spring & $=$ & Autumn & $<$ & Summer \\
\hline Synechococcus & Spring & $=$ & Winter & $<$ & Autumn & $=$ & Summer \\
\hline Prochlorococcus & Winter & $=$ & Autumn & $=$ & Spring & $<$ & Summer \\
\hline Picoeukaryotes & Winter & $<$ & Autumn & $<$ & Spring & $<$ & Summer \\
\hline \multicolumn{8}{|l|}{ Middle site } \\
\hline VLP & Winter & $<$ & Spring & $<$ & Autumn & $<$ & Summer \\
\hline VLP1 & Winter & $<$ & Spring & $=$ & Autumn & $<$ & Summer \\
\hline VLP2 & Winter & $<$ & Summer & $<$ & Spring & $<$ & Autumn \\
\hline Bacteria & Winter & $<$ & Autumn & $<$ & Spring & $<$ & Summer \\
\hline LDNA & Winter & $<$ & Autumn & $=$ & Spring & $<$ & Summer \\
\hline HDNA1 & Winter & $<$ & Autumn & $<$ & Spring & $<$ & Summer \\
\hline HDNA2 & Autumn & $=$ & Winter & $<$ & Spring & $<$ & Summer \\
\hline Synechococcus & Spring & $=$ & Winter & $<$ & Autumn & $<$ & Summer \\
\hline Prochlorococcus & Winter & $<$ & Spring & $<$ & Autumn & $<$ & Summer \\
\hline Picoeukaryotes & Winter & $<$ & Autumn & $<$ & Summer & $<$ & Spring \\
\hline \multicolumn{8}{|l|}{ Southern site } \\
\hline VLP & Spring & $<$ & Winter & $=$ & Summer & $<$ & Autumn \\
\hline VLP1 & Spring & $<$ & Winter & $=$ & Autumn & $<$ & Summer \\
\hline VLP2 & Spring & $<$ & Winter & $=$ & Summer & $<$ & Autumn \\
\hline Bacteria & Spring & $=$ & Winter & $=$ & Autumn & $<$ & Summer \\
\hline LDNA & Autumn & $=$ & Summer & $=$ & Spring & $=$ & Winter \\
\hline HDNA1 & Winter & $<$ & Spring & $<$ & Autumn & $<$ & Summer \\
\hline HDNA2 & Autumn & $=$ & Winter & $<$ & Spring & $<$ & Summer \\
\hline Synechococcus & Spring & $<$ & Summer & $<$ & Winter & $<$ & Autumn \\
\hline Prochlorococcus & Spring & $=$ & Winter & $<$ & Summer & $<$ & Autumn \\
\hline Picoeukaryotes & Winter & $<$ & Autumn & $<$ & Summer & $<$ & Spring \\
\hline
\end{tabular}



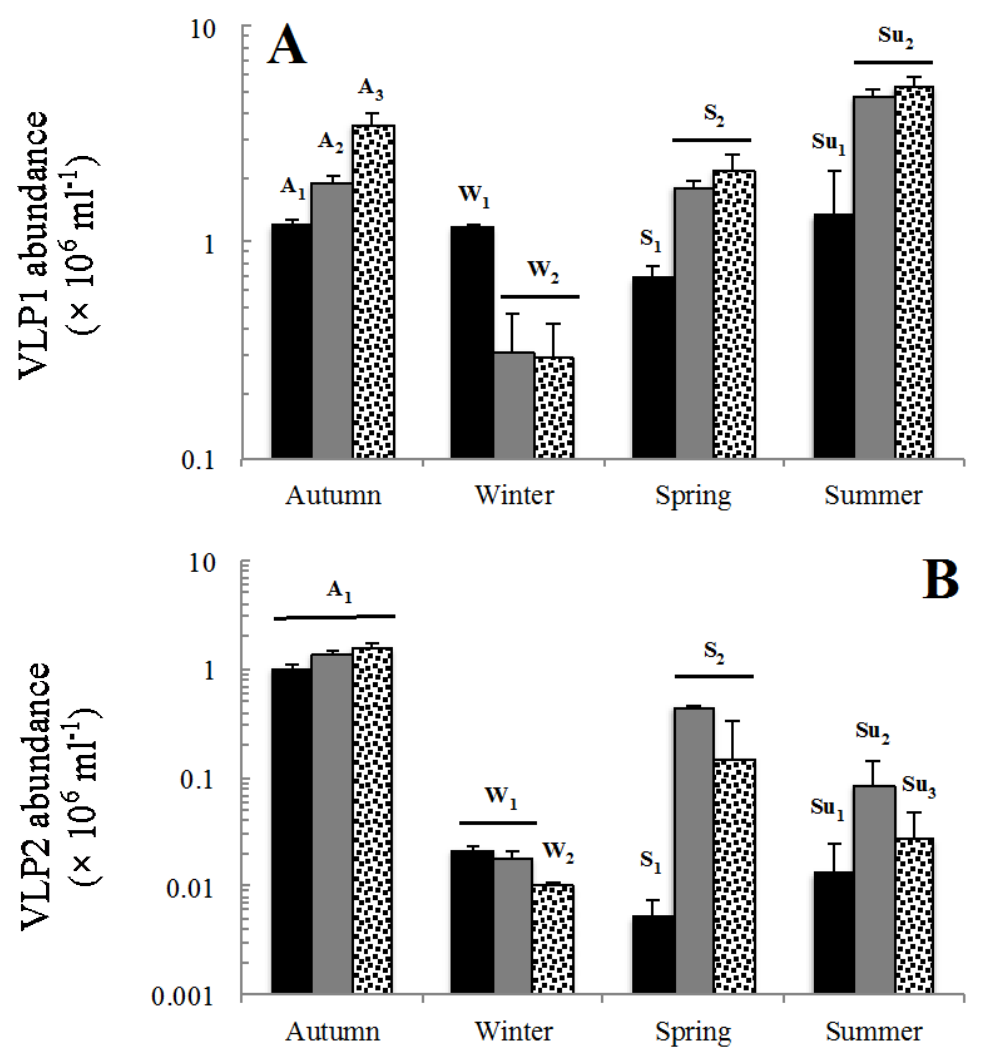

Figure 4. Abundance of viral sub-populations VLP1 (A) and VLP2 (B) at the Southern (black bars), Middle (grey bars) and Northern sites (dotted bars) in autumn, winter, spring and summer. The letters " $\mathrm{A}_{\mathrm{i}}$ ", " $\mathrm{W}_{\mathrm{i}}$ ", " $\mathrm{S}_{\mathrm{i}}$ " and "Su," identify significant differences $(p<0.05)$ inferred for each season using the Kruskal-Wallis test, and a subsequent multiple comparison procedure based on the Tukey test. Error bars are standard deviations.

dance $(p<0.01)$. VLP1 abundance was also significantly correlated with LDNA, HDNA1 and HDNA2 abundances $(p<0.01)$. In contrast, VLP2 abundance did not exhibit any significant correlation with LDNA, HDNA1 or HDNA2 abundance $(p>0.05)$. While site-specific temporal patterns exist, LDNA, HDNA1 and HDNA2 abundances are overall significantly less abundant in winter than in summer at all sites (Table 2).

\subsection{Picophytoplankton Abundance}

Two populations of prokaryotic phytoplankton (Synechococcus and Prochlorococcus) and one population of picoeukaryotic phytoplankton were consistently identified at all sites over the four seasons (Figure 2(b)). Synechococcus, Prochlorococcus and picoeukaryote abundance ranged from $4.25 \times 10^{2}$ to $7.67 \times 10^{4}$ cells ml $^{-1}$, 1.56 $\times 10^{3}$ to $2.91 \times 10^{4}$ cells ml $^{-1}$ and $2.07 \times 10^{2}$ to $1.68 \times 10^{3}$ cells ml $^{-1}$, respectively. Picoeukaryotes were significantly less abundant than Synechococcus and Prochlorococcus at all sites and seasons $(p>0.05)$; they hence accounted for $0.5 \%$ to $6.5 \%$ of picophytoplankton abundance, except in spring at the Southern site where they represented between $39.7 \%$ and $44.3 \%$ of the picophytoplankton community. All three picophytoplankton populations reached their peak abundance at the Northern site in summer (Figure 6), but exhibit significant spatial and temporal patterns of variability (KW test, $p<0.05)$. Specifically, their abundance significantly $(p<0.05)$ differed between sites for each season (Figure 6), and show complex temporal patterns of variability that are both population- and site-dependent (Figure 6, Table 2). Highly significant correlation was found between Synechococcus and Prochlorococcus $(p<0.01$ ), and their abundance was significantly positively correlated with most viral and bacterial sub-populations. In contrast, the abundance of picoeukaryotes did not exhibit any significant correlation with either Synechococcus or Prochlorococcus ( $p>0.05$ ), and were only significantly correlated with total bacterial abundance, HDNA1 and HDNA2 (Table 2). 

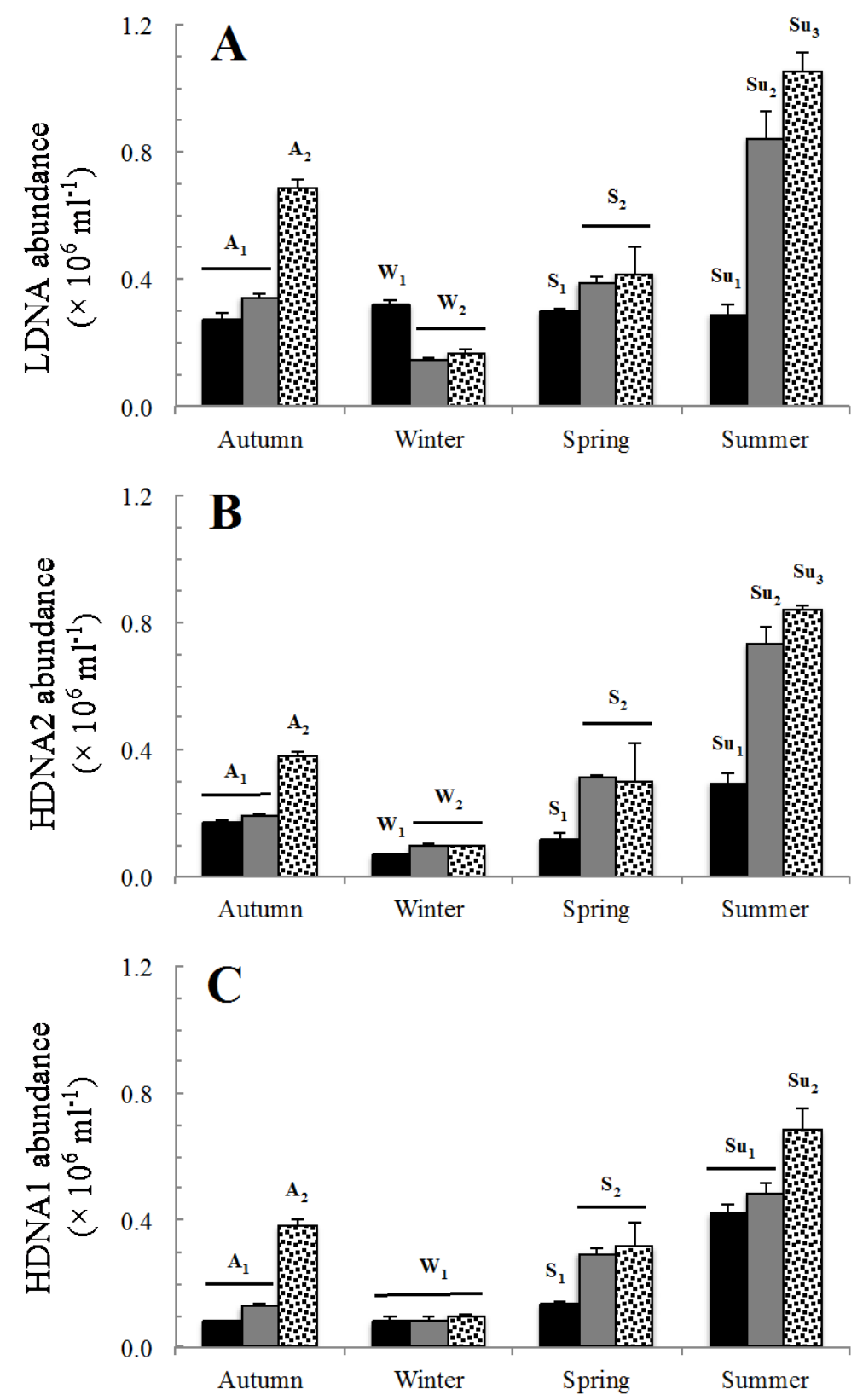

Figure 5. Abundance of heterotrophic bacteria sub-populations LDNA (A), HDNA1 (B) and HDNA2 (C) at the Southern (black bars), Middle (grey bars) and Northern (dotted bars) sites in autumn, winter, spring and summer. The letters " $\mathrm{A}_{\mathrm{i}}$ ", " $\mathrm{W}_{\mathrm{i}}$ ", " $\mathrm{S}_{\mathrm{i}}$ " and "Su $\mathrm{u}_{\mathrm{i}}$ " identify significant differences $(p<0.05)$ inferred for each season using the Kruskal-Wallis test, and a subsequent multiple comparison procedure based on the Tukey test. Error bars are standard deviations.

\subsection{Mortality Rates}

\subsubsection{Bacterial Mortality}

The rates of viral lysis and microzooplankton grazing of heterotrophic bacteria were estimated for each site in spring, summer, autumn and winter. No samples were available for the Southern site in autumn. Bacterial mortality rates were highly variable both between sites and between seasons (Figure 7). Specifically, no microzooplankton grazing was observed in spring across all sites, and in winter at the Southern site. Microzooplank 

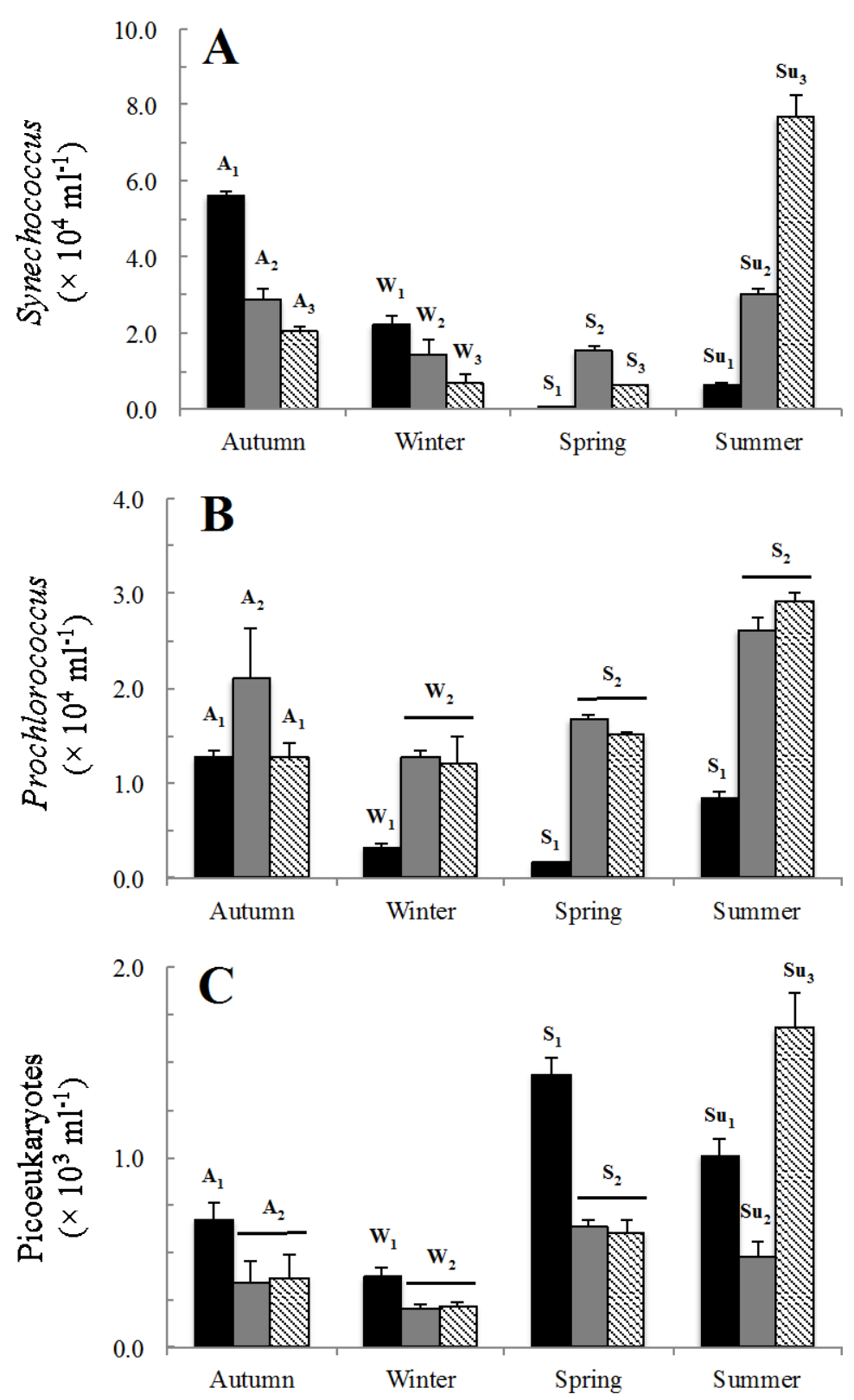

Figure 6. Abundance of prokaryotic (Synechococcus, (A); Prochlorococcus, (B)) and eukaryotic (C) picophytoplankton at the Southern (black bars), Middle (grey bars) and Northern (dotted bars) sites in autumn, winter, spring and summer. The letters " $\mathrm{A}_{\mathrm{i}}$ ", " $\mathrm{W}_{\mathrm{i}}$ ", " $\mathrm{S}_{\mathrm{i}}$ " and "Su," identify significant differences $(p<0.05)$ inferred for each season using the Kruskal-Wallis test, and a subsequent multiple comparison procedure based on the Tukey test. Error bars are standard deviations.

ton grazing rates, however, ranged from 0.37 to $0.57 \mathrm{~d}^{-1}$ in summer, 0.24 to $0.40 \mathrm{~d}^{-1}$ in autumn and 0.00 and $0.28 \mathrm{~d}^{-1}$ in winter. No microzooplankton grazing was observed in spring. Bacterial losses due to viral lysis were observed at all sites in spring, summer and autumn; no viral lysis was, however, observed in winter. Viral lysis ranged from 0.13 to $0.44 \mathrm{~d}^{-1}$ in spring, 0.02 to $0.06 \mathrm{~d}^{-1}$ in summer and 0.33 and $0.58 \mathrm{~d}^{-1}$ in autumn. Bacterial mortality was markedly dominated by microzooplankton grazing in summer at all sites and in winter at sites B and C (Figure 7). In contrast, mortality was essentially due to viral lysis in spring at all sites and in autumn at sites B and C (Figure 7). 


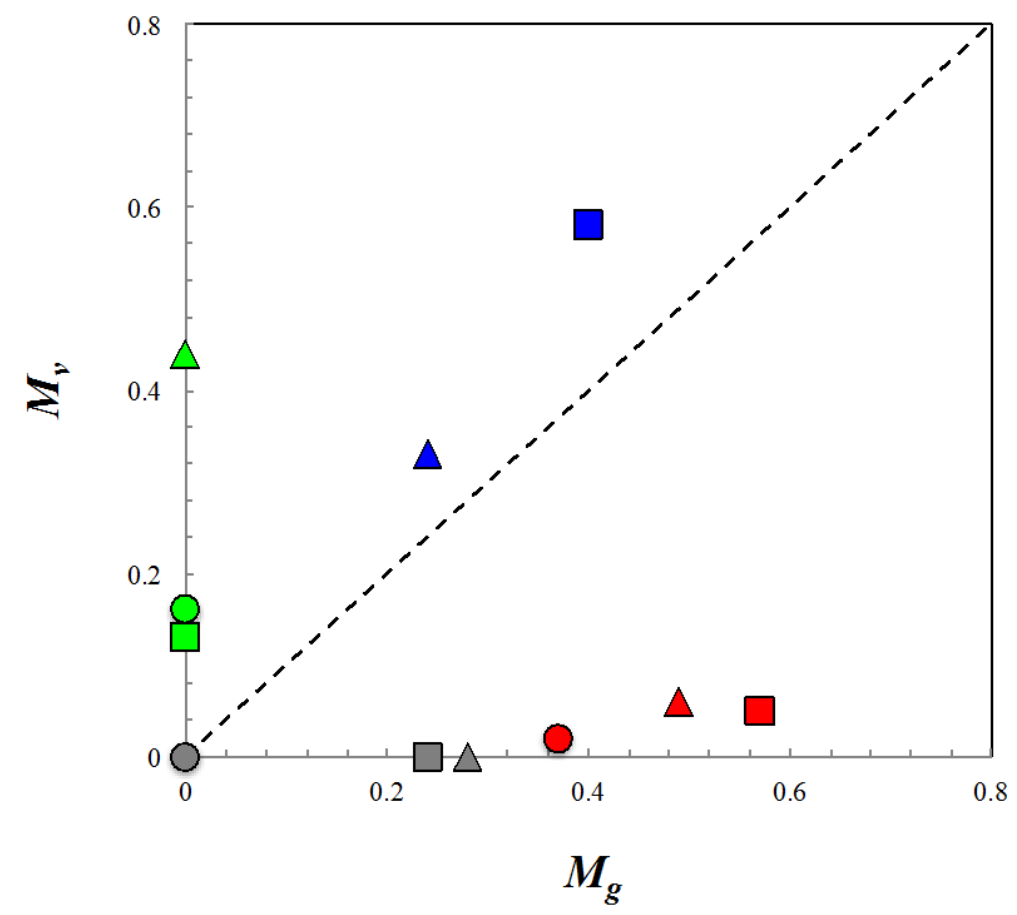

Figure 7. Mortality rates of heterotrophic bacteria due to microzooplankton grazing $\left(M_{a}, \mathrm{~d}^{-1}\right)$ and viral lysis $\left(M_{v}, \mathrm{~d}^{-1}\right)$ at the Southern (circles), Middle (triangles) and Northern (squares) sites in spring (green), summer (red), autumn (blue) and winter (grey). The dashed line indicates the situation where $M_{g}=M_{v}$.

\subsubsection{Picophytoplankton Mortality}

The rates of grazing by microzooplankton and viral lysis of Synechococcus, Prochlorococcus and picoeukaryotes were estimated for each site in spring, summer, autumn and winter (Table 3). No samples were available at the Southern site in autumn, and for viral lysis for the Northern site in winter. As observed for the mortality rates of heterotrophic bacteria (Figure 7), the mortality rates due to microzooplankton grazing and viral lysis were highly variable between sites and season for a given population, but also between populations (Table 3). More specifically, the mortality due to microzooplankton grazing ranged from 0.00 to $0.28 \mathrm{~d}^{-1}$ for Synechococcus, 0.00 and $0.16 \mathrm{~d}^{-1}$ for Prochlorococcus, and 0.00 and $0.12 \mathrm{~d}^{-1}$ for picoeukaryotes (Table 3). Viral lyses were also very variable, ranging from 0.00 to $0.09 \mathrm{~d}^{-1}$ for Synechococcus, 0.00 and $0.14 \mathrm{~d}^{-1}$ for Prochlorococcus, and 0.00 and $0.08 \mathrm{~d}^{-1}$ for picoeukaryotes (Table 3). In contrast to the observations conducted on bacterial mortality rates (Figure 7), no clear seasonality was found in the dominance of mortality due to grazing and viral lysis at any of the sites (Table 3).

\section{Discussion}

The cytometric community composition and the abundance of viruses, heterotrophic bacteria and both prokaryotic (Synechococcus and Prochlorococcus) and eukaryotic picophytoplankton were consistent with previous observations conducted in South Australian continental shelf waters, and more generally in eutrophic and oligotrophic waters; see [66]-[69] and references within.

\subsection{Community Composition and Abundance}

\subsubsection{Viruses}

Two populations of viral populations were identified based on their differences in green fluorescence and SSC (Figure 2(a)). More specifically, the cytometric signature of the two viral populations VLP1 and VLP2 consistently observed across the Spencer Gulf has also commonly been reported in a variety of environments and consistently considered as bacteriophages [61] [64]-[67]. Note that no viral sub-group characterized by either 
Table 3. Viral lysis and microzooplankton grazing $\left(\mathrm{d}^{-1}\right)$ for picoeukaryoteic (Euk) and prokaryotic (Synechococcus and Prochlorococcus; Syn and Proc) phytoplankton.

\begin{tabular}{|c|c|c|c|c|c|c|}
\hline SPRING & Syn & & Proc & & Euk & \\
\hline & $M_{g}$ & $M_{v}$ & $M_{g}$ & $M_{v}$ & $M_{g}$ & $M_{v}$ \\
\hline Northern site & 0 & 0 & 0.041 & 0.015 & 0.045 & 0 \\
\hline Middle site & 0 & 0.087 & 0 & 0 & 0 & 0 \\
\hline Southern site & 0.276 & 0 & 0 & 0.061 & 0 & 0.056 \\
\hline \multirow[t]{2}{*}{ SUMMER } & Syn & & Proc & & Euk & \\
\hline & $M_{g}$ & $M_{v}$ & $M_{g}$ & $M_{v}$ & $M_{g}$ & $M_{v}$ \\
\hline Northern site & 0 & 0.044 & 0.031 & 0.004 & 0.022 & 0.026 \\
\hline Middle site & 0.073 & 0.046 & 0 & 0.049 & 0 & 0 \\
\hline Southern site & 0.103 & 0.073 & 0.048 & 0.069 & 0.097 & 0.069 \\
\hline \multirow[t]{2}{*}{ AUTUMn } & Syn & & Proc & & Euk & \\
\hline & $M_{g}$ & $M_{v}$ & $M_{g}$ & $M_{v}$ & $M_{g}$ & $M_{v}$ \\
\hline Northern site & - & - & - & - & - & - \\
\hline Middle site & 0.087 & 0.016 & 0 & 0.136 & 0 & 0.084 \\
\hline Southern site & 0.086 & 0 & 0.159 & 0 & 0.125 & 0 \\
\hline \multirow[t]{2}{*}{ WINTER } & Syn & & Proc & & Euk & \\
\hline & $M_{g}$ & $M_{v}$ & $M_{g}$ & $M_{v}$ & $M_{g}$ & $M_{v}$ \\
\hline Northern site & 0 & 0 & 0.035 & 0 & 0.124 & 0.040 \\
\hline Middle site & 0 & 0 & 0 & 0 & 0 & 0 \\
\hline Southern site & 0.084 & - & 0 & - & 0 & - \\
\hline
\end{tabular}

similar levels of SYBR Green fluorescence than VLP2 but a greater size, or similar size but greater levels of SYBR Green fluorescence were observed, suggesting the absence of phytoplankton viruses that are generally characterized by higher side scatter and/or green fluorescence signatures [14]-[16] [70]-[72]. Noticeably, VLP1 abundance was significantly correlated with LDNA, HDNA1 and HDNA2 abundances. VLP2 abundance, however, did not exhibit any significant correlation with LDNA, HDNA1 or HDNA2 abundance. It was, however, significantly correlated to the abundance of Synechococcus and Prochlorococcus. These results hence suggest that while commonly considered as bacteriophages, the viral populations VLP1 and VLP2 may instead be, at least in the specific case of the Spencer Gulf, be respectively composed of bacteriophages and viruses infecting prokaryotic phytoplankton. Further work based on e.g. virus PFGE fingerprinting is, however, needed to confirm this theory.

\subsubsection{Heterotrophic Bacteria}

The sub-populations of heterotrophic bacteria identified through flow cytometry are consistently relatively low; we consistently identified three sub-populations of heterotrophic bacteria (LDNA, HDNA1, HDNA2) at all sites over the four seasons (Figure 2(a)). This result is comparable to observations conducted at various coastal locations around the south-west of the Spencer Gulf where the microbial community was limited to one LDNA and one HDNA sub-populations [73], and in the coastal waters of the nearby Saint Vincent Gulf, where heterotrophic bacteria were consistently composed of three sub-populations [73] [74] comparable to the LDNA, HDNA1 and HDNA2 sub-populations described here (Figure 2(a)). In contrast to our observations, the cytometric diversity of heterotrophic bacteria previously reported in South Australian coastal waters seems to vary seasonally [75] [76]. For instance, the cytometric diversity of the bacterial community observed in a mangrove estuary drastically increase from summer to autumn [75]. In summer, the bacterial community was divided into three 
discrete groups, based on their increasing SYBR Green fluorescence. The low DNA (LDNA) and high DNA (HDNA) populations generally evident in most aquatic systems [63] were clearly present in all samples. The HDNA population also exhibited two well defined peaks on histogram plots of SYBR Green fluorescence as observed here (see Figure 2(a)) and could subsequently be divided further into HDNA I and HDNA II categories. In autumn, however, the bacterial community was characterized by a substantially different "cytometric structure". While the LDNA, HDNA I and HDNA II populations were all still present, at least two more sub-populations were evident within all samples. Two additional populations were hence defined based respectively on their much higher SYBR Green fluorescence and higher levels of side scatter than the other bacterial subpopulations [75]. The low cytometric diversity reported in the coastal waters of both the Spencer Gulf [73], present work] and the Saint Vincent Gulf [73]-[75] sharply contrast, however, with other observations conducted in South Australian water bodies. For instance, up to seven sub-populations of heterotrophic bacteria of increasing size and DNA content were identified in the Coorong, a hypersaline coastal lagoon [76]. While further work is needed to confirm this hypothesis, these observations suggest that the dynamics of the microbial communities of the Spencer Gulf and the Saint Vincent Gulf may be relatively different, and both significantly limited. Noticeably LDNA bacteria were consistently significantly the most abundant group of heterotrophic bacteria (totaling from $29 \%$ to $68 \%$ of total bacterial abundance) and were up to 10 -fold more abundant than previously reported in South Australian continental shelf waters [66] [67], including the nearby Saint Vincent Gulf [73] [74] [77]. Specifically, sub-populations of heterotrophic bacteria characterized by a low DNA content have been suggested to be either inactive or dormant cells; sub-populations with DNA content represent, in turn, active cells [62] [63] [78] [79]. This has, however, been challenged and LDNA cells may also be active [80]-[83]. In addition, while having lower metabolic rates than HDNA cells, LDNA cells have been suggested to play a greater role in heterotrophic processes than HDNA cells in upwelling-driven eutrophic systems [81]. As such, the high relative abundance of LDNA cells consistently observed in the Spencer Gulf may also indicate a prominent role of these cells in oligotrophic waters.

\subsubsection{Picophytoplankton}

To our knowledge, the space-time dynamics of prokaryotic (Synechococcus and Prochlorococcus) and eukaryotic picophytoplankton has only been investigated in South Australian waters along a salinity gradient occurring along a hypersaline coastal lagoon [84], and from a few stations scattered along the $100 \mathrm{~m}$ isobaths on the South Australian continental shelf near the mouth of the Spencer Gulf [68] [69]. Specifically, six picophytoplankton populations were identified by flow cytometry, including two Synechococcus populations, two Prochlorococcus populations, and two groups of small and large picoeukaryotes. The abundance of each of these populations was controlled by a range of physical processes, including downwelling and dense waters outflowing from the Spencer Gulf in winter, early spring, upwelling in summer and early spring and eddy formation in summer. These processes resulted in up to four orders of magnitude changes in their abundances, and population-specific hotspots [69]. Note that the unexpected high abundances and local dominance of Prochlorococcus in summer was hypothesized to result from eastward and westward current transports and the presence of a High-Light and Low-Light ecotypes [69]. Our results are consistent with the seasonality in physical forcing characterizing the Spencer Gulf, with a clear dichotomy between winter and summer in the abundance of Synechococcus, Prochlorococcus and picoeukaryotes at the Northern and Middle sites, while the distinct temporal patterns observed from the Southern site is likely the result of the influence of the complex physical processes occurring on continental shelf waters (Table 2).

\subsection{Viruses and Microzooplankton as Mortality Agents}

There is a plethora of published papers quantifying the role of microzooplankton grazing rates in the ocean, see [19] for a review, and a vivid debate around the reliability of their estimates [85]-[87]. In contrast, studies reporting mortality rates due to both microzooplankton grazing and viral lysis on planktonic organisms are still very scarce [14]-[16] [20], with so far only one study which investigated the impact of grazing and lysis on heterotrophic bacteria [88]. Microzooplankton grazing pressures on total chlorophyll generally reported for coastal and estuarine ecosystems typically range from 0.08 and $2.19 \mathrm{~d}^{-1}$; see [18] [19] for a review. More specifically, the grazing and viral lysis of a Micromonas spp. population estimated from a mesocosm experiment were respectively in the range $0.26-0.65 \mathrm{~d}^{-1}$ and $0.10-0.29 \mathrm{~d}^{-1}$ [20]. A study investigating the rates of viral lysis and grazing by microzooplankton of Phaeocystis globosa over the course of a spring bloom in the Southern Bight of 
the North Sea [14] reported highly variable virally mediated mortality rates $\left(0.01-0.35 \mathrm{~d}^{-1}\right)$ and grazing rates $\left(0.05-0.40 \mathrm{~d}^{-1}\right)$. Similar conclusions were reached by a study conducted in the Southern Ocean that showed both viral lysis $\left(0.00-0.11 \mathrm{~d}^{-1}\right)$ and grazing rates $\left(0.00-1.78 \mathrm{~d}^{-1}\right)$ being highly variable for four phytoplankton groups differing in size [16]. In the Coorong, a hypersaline coastal lagoon, grazing and lysis rates for phytoplankton standing stock averaged respectively $3.4 \mathrm{~d}^{-1}$ and $3.1 \mathrm{~d}^{-1}$, and for heterotrophic bacteria ranging from 0.02 to $1.67 \mathrm{~d}^{-1}$ and from 0.01 to $2.9 \mathrm{~d}^{-1}$, respectively [89]. A study that may be more comparable to the present one, though conducted in the oligotrophic waters of the Atlantic Ocean, found grazing and lyses rates bounded between 0.00 and $0.81 \mathrm{~d}^{-1}$ and 0.00 and $0.32 \mathrm{~d}^{-1}$ for picoeukaryotes, 0.00 and $0.12 \mathrm{~d}^{-1}$ and 0.07 and $0.25 \mathrm{~d}^{-1}$ for Synechococcus, and between 0.00 and $0.06 \mathrm{~d}^{-1}$ and 0.00 and $0.8 \mathrm{~d}^{-1}$ for Prochlorococcus [15].

These observations show that the microzooplankton grazing and viral lysis rates reported in the present work for heterotrophic bacteria are in the lower range of values previously reported in the literature, hence suggest 1) a weak transfer of microbially-mediated matter and energy towards the classical food chain, and 2) a weak transformation of this microbial materials as bioavailable dissolved organic matter. This low viral activity and the related low recycling of potentially growth-limiting nutrients [10] may hence be one explanation for the low chlorophyll concentration consistently observed across the Spencer Gulf ([22]-[25]; present study). The bacterial losses due to both microzooplankton grazing and viral losses then seem minimal in the coastal waters of the Spencer Gulf, even though their seasonality (Figure 7) suggests an overall dominance of grazing over viral lysis in summer and winter; the opposite holds true in spring, while microzooplankton grazers and viruses are equivalent mortality agents in autumn. In contrast, the microzooplankton grazing and viral lysis rates of Synechococcus, Prochlorococcus and picoeukaryotes are comparable to previous observations conducted in the oligotrophic waters of the Southern Ocean, which suggests that the mortality dynamics of these populations is similar to those encountered in other oligotrophic waters.

\subsection{Methodological Considerations}

The dilution assay used in this study has the advantage of excluding the use of a conversion factor and of minimizing the handling of the sample. Its use has been validated across different heterotrophic bacteria and algal host taxa [14]-[16] [20] [88]. Besides, the consistency between the viral lysis rates obtained using this approach and other methods assessing cell lysis in a range of phytoplankton [14] [15] and heterotrophic bacteria [88] guarantees the reliability of this assay to infer the effects of viruses on bacteria and phytoplankton mortality. We nevertheless recall hereafter a few potential limitations of the methods that need to be kept in mind when interpreting its results.

First, this assay only detects the lysis of hosts that are newly produced, hence favors lytic infection in fast growing species [20], which hence may lead to overestimate viral lysis; see also [14] for a detailed discussion. In turn, viral lysis is likely to be underestimated when viral infections occur in cells with reduced metabolism [89], which might be the case in environments dominated by low DNA bacteria such as the Spencer Gulf. In addition, recent results dissecting the effect of viruses on the mortality of distinct bacterial sub-populations showed that viruses preferentially infect the most abundant bacterial sub-populations [88]. This is consistent with the idea that host separation distance is the most important factor in defining virus success [90]. This also highlights the possibility that estimates of global mortality rates may only provide partial information on the "game" at play between viruses and their bacterial hosts.

Second, a fundamental assumption of the dilution assay is that host losses are proportional to the dilution effect on the abundance of the mortality agents. This implies that a single round of infection should be detected, hence that the host's cell lysis must occur later than $12 \mathrm{~h}$ after infection but within the 24-h incubation. Studies of bacterial and algal host-virus model systems (including prokaryotic algal hosts) indeed suggest that the time to cell lysis upon viral infection ranges within $24 \mathrm{~h}$ [91] [92]. A fundamental limitation of the dilution assay that has, however, to be stressed is related to the balance existing between lytic and lysogenic viral infection. A prophage can be induced into the lytic pathway either spontaneously or by physical or chemical factors [93], but little is still known on the relative importance of the two modes of infection [94]. Prophage not induced into the lytic pathway within $24 \mathrm{~h}$ would then intrinsically lead to underestimate viral lysis.

The dilution assay also assumed that there is no preferential grazing by microzooplankton. For instance, in case of preferential grazing upon infected cells, viral lysis would be underestimated, as suggested earlier [4]. A recent study dissecting the effect of microzooplankton grazing on the mortality of distinct bacterial sub-populations showed that the larger cell-sized bacterial sub-populations with greater DNA content experienced higher 
rates of microzooplankton predation [89]. While this is consistent with previous results indicating that medium to large sized bacteria, along with more active and dividing cells, are most susceptible to grazing [17], this is likely to bias bacterial mortality rates towards microzooplankton grazing.

Finally, reliable results of the dilution assay also rely on the absence of substantial loss of virus during the incubation. Grazing by heterotrophic nanoflagellates (HNFs) may be a source of viral loss, but reported rates of viral removal by HNFs are low enough, i.e. $\leq 0.3 \% \mathrm{~d}^{-1}$ [95], to be considered negligible.

\section{Conclusion}

We have shown that the relative impacts of viral lysis and microzooplankton grazing on heterotrophic bacteria and both prokaryotic and picoeukaryotic phytoplankton in the oligotrophic waters of the Spencer Gulf were very heterogeneous in space and time, specifically, viral lysis fuels primary and secondary productivity through the release of organic matter and nutrients, which shunts substrates to uninfected microbes. The relatively low mortality rates reported here for heterotrophic bacteria-in particular the low viral lysis rates and the related low recycling of potentially growth-limiting nutrients-are consistent with a bottom-up limitation of phytoplankton biomass and production. In turn, the phytoplankton mortality rates are similar to those reported in other oligotrophic waters, hence we suggest a top-down control of phytoplankton communities. More generally, our results-and in particular the observed space-time heterogeneity of the impact of mortality agents on heterotrophic bacteria and prokaryotic and picoeukaryotic phytoplankton-indicate that shifts in top-down and bottom-up pressures occurring in association with environmental variability should be carefully considered when assessing the effects of fluctuations and gradients in physical parameters on microbial assemblages. Taken together our findings, we suggest that the influence of viruses and microzooplankton grazers should not be considered as two clear-cut mortality causes but as a more complex set of varying factors, which (while working in parallel) can substantially shift in importance as a consequence of changes in both environmental and ecological parameters.

\section{Acknowledgements}

We thank the Captain and crew of the FV Atlas and SARDI staff for their assistance during the survey. We also thank James Patterson and Kelly Newton for their expertise and assistance with flow cytometry. This research was financially supported by the Australian Research Council's Discovery Projects funding scheme (Projects DP0664681 and DP0988554). Professor Seuront is the recipient of an Australian Professorial Fellowship (project number DP0988554). Mark Doubell and Paul van Ruth are supported by the South Australian Government through Marine Innovation South Australia (MISA).

\section{References}

[1] Furhman, J.A. (1999) Marine Viruses and Their Biogeochemical and Ecological Effects. Nature, 399, 541-548. http://dx.doi.org/10.1038/21119

[2] Suttle, C.A. (2005) Viruses in the Sea. Nature, 437, 356-361. http://dx.doi.org/10.1038/nature04160

[3] Suttle, C.A. (2007) Marine Viruses-Major Players in the Global Ecosystem. Nature Reviews Microbiology, 5, 801810. http://dx.doi.org/10.1038/nrmicro1750

[4] Ruardij, P., Veldhuis, M.J.W. and Brussaard, C.P.D. (2005) Modeling the Bloom Dynamics of the Polymorphic Phytoplankter Phaeocystis globosa: Impact of Grazers and Viruses. Harmful Algae, 4, 941-963. http://dx.doi.org/10.1016/j.hal.2004.12.011

[5] Poorvin, L., Rinta-Kanto, J.M., Hutchins, D.A. and Wilhelm, S.W. (2004) Viral Release of Fe and Its Bioavailability to Marine Plankton. Limnology and Oceanography, 49, 1734-1741. http://dx.doi.org/10.4319/lo.2004.49.5.1734

[6] Lawrence, J.E. and Suttle, C.A. (2004) Effect of Viral Infection of Sinking Rates of Heterosigma akashiwo and Its Implications for Bloom Termination. Aquatic Microbial Ecology, 37, 1-7. http://dx.doi.org/10.3354/ame037001

[7] Mari, X., Rassoulzadegan, F., Brussaard, C.P.D. and Wassmann, P. (2005) Dynamics of Transparent Exopolymeric Particles (TEP) Production by Phaeocystis globosa under N- or P-Limitation: A Controlling Factor of the Retention/ Export Balance. Harmful Algae, 4, 895-914. http://dx.doi.org/10.1016/j.hal.2004.12.014

[8] Wommack, K.E. and Colwell, R.R. (2000) Virioplankton: Viruses in Aquatic Ecosystems. Microbiology and Molecular Biology Reviews, 64, 69-114. http://dx.doi.org/10.1128/MMBR.64.1.69-114.2000

[9] Weinbauer, M.G. (2004) Ecology of Prokaryotic Viruses. FEMS Microbiology Reviews, 28, 127-181. http://dx.doi.org/10.1016/j.femsre.2003.08.001 
[10] Brussaard, C.P.D., Wilhem, S.W., Thingstad, F., Weinbauer, M.G., Bratbak, G., Heldal, M., Kimmance, S.A., Middelboe, M., Nagasaki, K., Paul, J.H., Schroeder, D.C., Suttle, C.A., Vaqué, D. and Wommack, K.E. (2008) Global-Scale Processes with a Nanoscale Drive: The Role of Marine Viruses. The ISME Journal, 2, 575-578. http://dx.doi.org/10.1038/ismej.2008.31

[11] Proctor, L.M. and Fuhrman, J.A. (1990) Viral Mortality of Marine Bacteria and Cyanobacteria. Nature, 343, 60-62. http://dx.doi.org/10.1038/343060a0

[12] Suttle, C.A. (1994) The Significance of Viruses to Mortality in Aquatic Microbial Communities. Microbial Ecology, 28, 237-243. http://dx.doi.org/10.1007/BF00166813

[13] Fuhrman, J.A. and Noble, R.T. (1996) Viruses and Protists Cause Similar Bacterial Mortality in Coastal Seawater. Limnology and Oceanography, 40, 1236-1242. http://dx.doi.org/10.4319/10.1995.40.7.1236

[14] Baudoux, A.C., Noordeloos, A.A.M., Veldhuis, M.J.W. and Brussaard, C.P.D. (2006) Virally Induced Mortality of Phaeocystis globosa during Two Spring Blooms in Temperate Coastal Waters. Aquatic Microbial Ecology, 44, 207217. http://dx.doi.org/10.3354/ame044207

[15] Baudoux, A.C., Veldhuis, M.J.W., Witte, H.J. and Brussaard, C.P.D. (2007) Viruses as Mortality Agents of Picophytoplankton in the Deep Chlorophyll Maximum Layer during Ironages III. Limnology and Oceanography, 52, 2519-2529. http://dx.doi.org/10.4319/lo.2007.52.6.2519

[16] Brussaard, C.P.D., Timmermans, K.R., Uitz, J. and Veldhuis, M.J.W. (2008) Virioplankton Dynamics and Virally Induced Phytoplankton Lysis versus Microzooplankton Grazing Southeast of the Kerguelen (Southern Ocean). Deep Sea Research Part II: Topical Studies in Oceanography, 55, 752-765. http://dx.doi.org/10.1016/j.dsr2.2007.12.034

[17] Sherr, E.B. and Sherr, B.F. (2002) Significance of Predation by Protists in Aquatic Microbial Food Webs. Antonie van Leeuwenhoek, 81, 293-308. http://dx.doi.org/10.1023/A:1020591307260

[18] Calbet, A. and Landry, M.R. (2004) Phytoplankton Growth, Microzooplankton Grazing, and Carbon Cycling in Marine Systems. Limnology and Oceanography, 49, 51-57. http://dx.doi.org/10.4319/lo.2004.49.1.0051

[19] Schmoker, C., Hernández-León, S. and Calbet, A. (2013) Microzooplankton Grazing in the Oceans: Impacts, Data Variability, Knowledge Gaps and Future Directions. Journal of Plankton Research, 35, 691-706. http://dx.doi.org/10.1093/plankt/fbt023

[20] Evans, C., Archer, S.D., Jacquet, S. and Wilson, W.H. (2003) Direct Estimates of the Contribution of Viral Lysis and Microzooplankton Grazing to the Decline of a Micromonas spp. Population. Aquatic Microbial Ecology, 30, 207-219. http://dx.doi.org/10.3354/ame030207

[21] Tomczak, M. and Godfrey, J.S. (1994) Regional Oceanography: An Introduction. Pergamon Press, Oxford.

[22] van Ruth, P., Thompson, P., Blackburn, S. and Bonham, P. (2009) Temporal and Spatial Variability in Phytoplankton Abundance and Community Composition, and Pelagic Biogeochemistry in the Tuna Farming Zone. In: Tanner, J.E. and Volkman, J., Eds., Aquafin CRC: Southern Bluefin Tuna Aquaculture Subprogram: Risk and Response, Understanding the Tuna Farming Environment, Aquafin CRC, Fisheries Research \& Development Corporation and South Australian Research \& Development Institute (Aquatic Sciences), Adelaide, SARDI Research Report Series No. 344,287 p.

[23] van Ruth, P., Bonham, P., Jones, E. and Thompson, P. (2009) Plankton Ecology: Primary Productivity, Zooplankton Community Composition and Grazing. In: Tanner, J.E. and Volkman, J., Eds., Aquafin CRC: Southern Bluefin Tuna Aquaculture Subprogram: Risk and Response, Understanding the Tuna Farming Environment, Aquafin CRC, Fisheries Research \& Development Corporation and South Australian Research \& Development Institute (Aquatic Sciences), Adelaide, SARDI Research Report Series No. 344, 287 p.

[24] van Ruth, P., Thompson, P., Bonham, P. and Jones, E. (2009) Primary Productivity and Zooplankton Ecology in the Port Lincoln Tuna Farming Zone. Technical Report, Aquafin CRC Project 4.6, FRDC Project 2005/059. Aquafin CRC, Fisheries Research \& Development Corporation and South Australian Research \& Development Institute (Aquatic Sciences), Adelaide, SARDI Research Report Series No 343, 58 pp.

[25] Van Ruth, P.D. and Doubell, M.J. (2013) Spatial and Temporal Variation in Primary and Secondary Productivity and Lower Trophic Ecosystem Function in Spencer Gulf, South Australia. In: Middleton, J.F., Ed., PIRSA Initiative II: Carrying Capacity of Spencer Gulf: Hydrodynamic and Biogeochemical Measurement, Modelling and Performance Monitoring, FRDC Project No. 2009/046, SARDI Publication, South Australian Research and Development Institute (Aquatic Sciences), Adelaide, SARDI Research Report Series No. 705, 97 p.

[26] Fuller, M.K., Bone, Y., Gostin, V.A. and Von Der Borch, C.C. (1994) Holocene Cool-Water Carbonate and Terrigenous Sediments from Southern Spencer Gulf, South Australia. Australian Journal of Earth Sciences: An International Geoscience Journal of the Geological Society of Australia, 41, 353-363. http://dx.doi.org/10.1080/08120099408728144

[27] Harris, P.T. (1994) Comparison of Tropical, Carbonate and Temperate, Siliciclastic Tidally Dominated Sedimentary 
Deposits: Examples from the Australian Continental Shelf. Australian Journal of Earth Sciences: An International Geoscience Journal of the Geological Society of Australia, 41, 241-254. http://dx.doi.org/10.1080/08120099408728133

[28] Porter-Smith, R., Harris, P.T., Andersen, O.B., Coleman, R., Greeslade, D. and Jenkins, C.J. (2004) Classification of the Australian Continental Shelf Based on Predicted Sediment Threshold Exceedance from Tidal Currents and Swell Waves. Marine Geology, 211, 1-20. http://dx.doi.org/10.1016/j.margeo.2004.05.031

[29] Schwarz, M.P. (2003) Lincoln, South Australia: Sheet SI53-11 International Index. 1:250 000 Geological Series Explanatory Notes (Geological Survey of South Australia). Primary Industries and Resources South Australia, Adelaide.

[30] Nunes, R.A. and Lennon, G.W. (1986) Physical Property Distributions and Seasonal Trends in Spencer Gulf, South Australia: An Inverse Estuary. Australian Journal of Marine and Freshwater Research, 37, 39-53. http://dx.doi.org/10.1071/MF9860039

[31] Smith, S.V. and Veeh, H.H. (1989) Mass Balance of Biogeochemically Active Materials (C,N,P) in a Hypersaline Gulf. Estuarine, Coastal and Shelf Science, 29, 195-215. http://dx.doi.org/10.1016/0272-7714(89)90053-X

[32] Vaz, R.N., Lennon, G. and Bowers, D. (1990) Physical Behaviour of a Large, Negative or Inverse Estuary. Continental Shelf Research, 10, 277-304. http://dx.doi.org/10.1016/0278-4343(90)90023-F

[33] Lennon, G.W., Bowers, D.G., Nunes, R.A., Scott, B.D., Ali, M., Boyle, J., Cai, W., Herzfeld, M., Johansson, G., Nield, S., Petrusevics, P., Stephenson, P., Suskin, A.A. and Wijffels, S.E.A. (1987) Gravity Currents and the Release of Salt from an Inverse Estuary. Nature, 327, 695-697. http://dx.doi.org/10.1038/327695a0

[34] Kämpf, J. (2010) On Preconditioning of Coastal Upwelling in the Eastern Great Australian Bight. Journal of Geophysical Research: Oceans, 115, Published Online.

[35] Easton, A.K. (1978) A Reappraisal of the Tides in Spencer Gulf, South Australia. Australian Journal of Marine and Freshwater Research, 29, 467-477. http://dx.doi.org/10.1071/MF9780467

[36] Bullock, D.A. (1975) The General Water Circulation of Spencer Gulf, South Australia, in the Period February to May. Transactions of the Royal Society of South Australia, 99, 43-57.

[37] Hahn, S.D. (1986) Physical Structure of the Waters of the South Australian Continental Shelf. Ph.D. Thesis, School of Earth Sciences, Flinders University of South Australia, Bedford Park.

[38] Petrusevics, P., Bye, J., Luick, C.E.P. and Teixeira, C. (2011) Summer Sea Surface Temperature Fronts and Elevated Chlorophyll-a in the Entrance to Spencer Gulf, South Australia. Continental Shelf Research, 3, 849-856. http://dx.doi.org/10.1016/j.csr.2011.02.009

[39] Bruce, B.D. and Short, D.A. (1990) Observations on the Distribution of Larval Fish in Relation to a Frontal System at the Mouth of Spencer Gulf, South Australia. Bureau of Rural Resources Proceedings, 15, 124-137.

[40] McClatchie, S., Middleton, J.F. and Ward, T.M. (2006) Water Mass Analysis and Alongshore Variation in Upwelling Intensity in the Eastern Great Australian Bight. Journal of Geophysical Research: Oceans, 111, Published Online. http://dx.doi.org/10.1029/2004JC002699

[41] Department for Environment and Heritage (2009) A Technical Report on the Outer Boundaries of South Australia's Marine Parks Network. Department for Environment and Heritage, South Australia.

[42] Edyvane, K.S. (1999) Conserving Marine Biodiversity in South Australia, Part 1. Background, Status and Review of Approach to Marine Biodiversity Conservation in South Australia. South Australian Research and Development Institute Report Series, 38, 173 p.

[43] Edyvane, K.S. (1999) Conserving Marine Biodiversity in South Australia, Part 2. Identification of Areas of High Conservation Value in South Australia. South Australian Research and Development Institute, Aquatic Science Centre, Adelaide, 39, $281 \mathrm{p}$.

[44] Phillips, J.A. (2001) Marine Macroalgal Biodiversity Hotspots: Why Is There High Species Richness and Endemism in Southern Australian Marine Benthic Flora. Biodiversity and Conservation, 10, 1555-1577. http://dx.doi.org/10.1023/A:1011813627613

[45] Hall, K. and Fowler, A.J. (2003) The Fisheries Biology of the Cuttlefish Sepia apama Gray. South Australian Waters. Final Report to FRDC (Project No. 98/151). SARDI Aquatic Sciences, Adelaide, p. 289.

[46] Hall, K.C. and Hanlon, R.T. (2002) Principal Features of the Mating System of a Large Spawning Aggregation of the Giant Australian Cuttlefish Sepia apama (Mollusca: Cephalopoda). Marine Biology, 140, 533-545. http://dx.doi.org/10.1007/s00227-001-0718-0

[47] Strong, W.R., Bruce, B.D., Nelson, D.R. and Murphy, R.D. (1996) Population Dynamics of White Sharks in Spencer Gulf, South Australia. In: Klimley, A.P. and Ainley, D.G., Eds., Great White Shark: The Biology of Carcharodon carcharias, Academic Press, San Diego, 401-414. http://dx.doi.org/10.1016/B978-012415031-7/50038-0

[48] Baker, J.L. (2006) 4.22 Syngnathid Fish (Seahorses, Seadragons, Pipehorses and Pipefishes). The South-West Marine Region: Ecosystems and Key Species Groups: 469. 
[49] Browne, R.K., Baker, J.L. and Connolly, R.M. (2008) Syngnathids: Seadragons, Seahorses, and Pipefishes of Gulf St Vincent. In: Shepherd, S.A., Bryars, S., Kirkegaard, I.R., Harbison, P. and Jennings, J.T., Eds., Natural History of Gulf St Vincent, The University of Adelaide, Royal Society of South Australia (Inc.), Adelaide, 162-176.

[50] Svane, I. (2005) Occurrence of Dolphins and Seabirds and Their Consumption of By-Catch during Prawn Trawking in Spencer Gulf, South Australia. Fisheries Research, 76, 317-327. http://dx.doi.org/10.1016/j.fishres.2005.07.012

[51] Currie, D.R. and Sorokin, S.J. (2010) The Distribution and Trophodunamics of Demersal Fish from Spencer Gulf. Transactions of the Royal Society of South Australia, 134, 198-227.

[52] Econsearch (2013) The Economic Impact of Aquaculture on the South Australian State and Regional Economies, 2011/12. Report Prepared for PIRSA Aquaculture by Econsearch, Marryatville, 89 p.

[53] Gibbs, C.F., Tomczak, M. and Longmore, A.R. (1986) The Nutrient Regime of Bass Strait. Australian Journal of Marine and Freshwater Research, 37, 451-466. http://dx.doi.org/10.1071/MF9860451

[54] Hallegraeff, G.M. and Jeffrey, S.W. (1993) Annually Recurrent Diatom Blooms in Spring along the New South Wales Coast of Australia. Australian Journal of Marine and Freshwater Research, 44, 325-344. http://dx.doi.org/10.1016/j.csr.2005.04.003

[55] Hanson, C.E., Pattiaratchi, C.B. and Waite, A.M. (2005) Sporadic Upwelling on a Downwelling Coast: Phytoplankton Responses to Spatially Variable Nutrient Dynamics off the Gascoyne Region of Western Australia. Continental Shelf Research, 25, 1561-1582. http://dx.doi.org/10.1016/j.csr.2005.04.003

[56] van Ruth, P.D., Ganf, G.G. and Ward, T.M. (2010) Hot-Spots of Primary Productivity: An Alternative Interpretation to Conventional Upwelling Models. Estuarine, Coastal and Shelf Science, 90, 142-158. http://dx.doi.org/10.1016/j.ecss.2010.08.009

[57] Nunes-Vaz, R.D. (2012) The Salinity Response of an Inverse Estuary to Climate Change and Desalination. Estuarine, Coastal and Shelf Science, 98, 49-59. http://dx.doi.org/10.1016/j.ecss.2011.11.023

[58] Brussaard, C.P.D. (2004) Optimisation of Procedures for Counting Viruses by Flow Cytometry. Applied and Environmental Microbiology, 70, 1506-1513. http://dx.doi.org/10.1128/AEM.70.3.1506-1513.2004

[59] Gasol, J.M. and del Giorgio, P.A. (2000) Using Flow Cytometry for Counting Natural Planktonic Bacteria and Understanding the Structure of Planktonic Bacterial Communities. Scientia Marina, 64, 197-224.

[60] Marie, D., Partensky, F., Jacquet, S. and Vaulot, D. (1997) Enumeration and Cell Cycle Analysis of Natural Populations of Marine Picoplankton by Flow Cytometry Using the nucleic Acid Statin SYBR Green I. Applied and Environmental Microbiology, 63, 186-193.

[61] Marie, D., Brussaard, C.P.D., Thyrhaug, R., Bratbak, G. and Vaulot, D. (1999) Enumeration of Marine Viruses in Culture and Natural Samples by Flow Cytometry. Applied and Environmental Microbiology, 65, 45-52.

[62] Li, W.K.W., Jellett, J.F. and Dickie, P.M. (1995) DNA Distributions in Planktonic Bacteria Stained with TOTO or TOPRO. Limnology and Oceanography, 40, 1485-1495. http://dx.doi.org/10.4319/lo.1995.40.8.1485

[63] Gasol, J.M., Zweifel, U.L., Peters, F., Fuhrman, J.A. and Hagström, A. (1999) Significance of Size and Nucleic Acid Content Heterogeneity as Measured by Flow Cytometry in Natural Planktonic Bacteria. Applied and Environmental Microbiology, 65, 4475-4483.

[64] Brussaard, C.P.D., Kuipers, B. and Veldhuis, M.J.W. (2005) A Mesocosm Study of Phaeocytis globosa Population Dynamics: I. Regulatory Role of Viruses in Bloom Culture. Harmful Algae, 4, 859-874. http://dx.doi.org/10.1016/j.hal.2004.12.015

[65] Seymour, J.R., Seuront, L., Doubell, M.J., Waters, R.L. and Mitchell, J.G. (2006) Microscale Patchiness of Virioplankton. Journal of the Marine Biological Association of the United Kingdom, 86, 551-561. http://dx.doi.org/10.1017/S0025315406013464

[66] Paterson, J.S., Nayar, S., Mitchell, J.G. and Seuront, L. (2012) A Local Upwelling Controls Viral and Microbial Community Structure within South Australian Continental Shelf Waters. Estuarine, Coastal and Shelf Science, 96, 197-208. http://dx.doi.org/10.1016/j.ecss.2011.11.009

[67] Paterson, J.S., Nayar, S., Mitchell, J.G. and Seuront, L. (2013) Population-Specific Shifts in Viral and Microbial Abundance within a Cryptic Upwelling. Journal of Marine Systems, 113-114, 52-61. http://dx.doi.org/10.1016/j.jmarsys.2012.12.009

[68] van Dongen-Vogels V., Seymour, J.R., Middleton, J.F., Mitchell, J.G. and Seuront, L. (2012) Shifts in Picophytoplankton Community Structure Influenced by Changing Upwelling Conditions. Estuarine, Coastal and Shelf Science, 109, 81-90. http://dx.doi.org/10.1016/j.ecss.2012.05.026

[69] Van Dongen-Vogels, V., Seymour, J.R., Middleton, J.F., Mitchell, J.G. and Seuront, L. (2011) Influence of Local Physical Events Drive Picophytoplankton Spatial and Temporal Dynamics in South Australian Continental Shelf Waters. Journal of Plankton Research, 33, 1825-1841. http://dx.doi.org/10.1093/plankt/fbr077 
[70] Baudoux, A.C. and Brussaard, C.P.D. (2005) Characterization of Different Viruses Infecting the Marine Harmful Algal Bloom Species Phaeocystis globosa. Virology, 341, 80-90. http://dx.doi.org/10.1016/j.hal.2004.12.015

[71] Brussaard, C.P.D., Thyrhaug, R., Marie, D. and Bratbak, G. (1999) Flow Cytometric Analyses of Viral Infection in Two Marine Phytoplankton Species, Micromonas pusilla (Prasinophyceae) and Phaeocystis pouchetii (Prymnesiophyceae). Journal of Phycology, 35, 941-948.

[72] Larsen, J.B., Larsen, A., Thyrhaug, R., Bratbak, G. and Sandaa, R.A. (2008) Response of Marine Viral Populations to a Nutrient Induced Phytoplankton Bloom at Different $\mathrm{pCO}_{2}$ Levels. Biogeosciences, 5, 523-533. http://dx.doi.org/10.5194/bg-5-523-2008

[73] Schapira, M., Pollet, T., Mitchell, J.G. and Seuront, L. (2009) Respiration Rates in Marine Heterotrophic Bacteria Relate to the Cytometric Characteristics of Bacterioplankton Communities. Journal of the Marine Biological Association of the United Kingdom, 89, 1161-1169. http://dx.doi.org/10.1017/S0025315409000617

[74] Seymour, J.R., Seuront, L. and Mitchell, J.G. (2005) Microscale and Small-Scale Temporal Dynamics of a Coastal Planktonic Microbial Community. Marine Ecology Progress Series, 300, 21-37. http://dx.doi.org/10.3354/meps300021

[75] Seymour, J.R., Seuront, L. and Mitchell, J.G. (2007) Microscale Gradients of Planktonic Microbial Communities Above the Sediment Surface in a Mangrove Estuary. Estuarine, Coastal and Shelf Science, 73, 651-666. http://dx.doi.org/10.1016/j.ecss.2007.03.004

[76] Schapira, M., Buscot, M.J., Leterme, S.C., Pollet, T., Chapperon, C. and Seuront, L. (2009) Distribution of Heterotrophic Bacteria and Virus-Like Particles along a Salinity Gradient in a Hypersaline Coastal Lagoon. Aquatic Microbial Ecology, 54, 171-183. http://dx.doi.org/10.3354/ame01262

[77] Seymour, J.R., Seuront, L. and Mitchell, J.G. (2004) Microscale Heterogeneity in the Activity of Coastal Bacterioplankton Communities. Aquatic Microbial Ecology, 35, 1-16. http://dx.doi.org/10.3354/ame035001

[78] Lebaron, P., Servais, P., Agogué, H., Courties, C. and Joux, F. (2001) Does the High Nucleic Acid Content of Individual Bacterial Cells Allow Us to Discriminate between Active Cells and Inactive Cells in Aquatic Systems? Applied and Environmental Microbiology, 67, 1775-1782. http://dx.doi.org/10.1128/AEM.67.4.1775-1782.2001

[79] Servais, P., Casamayor, E.O., Courties, C., Catala, P., Parthuisot, N. and Lebaron, P. (2003) Activity and Diversity of Bacterial Cells with High and Low Nucleic Acid Content. Aquatic Microbial Ecology, 33, 41-51. http://dx.doi.org/10.3354/ame033041

[80] Zubkov, M.V., Fuchs, B.M., Burkill, P.H. and Amann, R. (2001) Comparison of Cellular and Biomass Specific Activities of Dominant Bacterioplankton Groups in Stratified Waters of the Celtic Sea. Aquatic Microbial Ecology, 67, 52105218.

[81] Longnecker, K., Sherr, B.F. and Sherr, E.B. (2005) Activity and Phylogenetic Diversity of Bacterial Cells with High and Low Nucleic Acid Content and Electron Transport System Activity in an Upwelling Ecosystem. Applied and Environmental Microbiology, 71, 7737-7749. http://dx.doi.org/10.1128/AEM.71.12.7737-7749.2005

[82] Bouvier, T., Del Giorgio, P.A. and Gasol, J.M. (2007) A Comparative Study of the Cytometric Characteristics of High and Low Nucleic-Acid Bacterioplankton Cells from Different Aquatic Ecosystems. Environmental Microbiology, 9, 2050-2066. http://dx.doi.org/10.1111/j.1462-2920.2007.01321.x

[83] Wang, Y., Hammes, F., Boon, N., Chami, M. and Egli, T. (2009) Isolation and Characterization of Low Nucleic Acid (LNA)-Content Bacteria. The ISME Journal, 3, 889-902. http://dx.doi.org/10.1038/ismej.2009.46

[84] Schapira, M., Buscot, M.J., Pollet, T., Leterme, S.C. and Seuront, L. (2010) Distribution of Picophytoplankton Communities from Brackish to Hypersaline Waters in a South Australian Coastal Lagoon. Saline Systems, 6, 2. http://dx.doi.org/10.1186/1746-1448-6-2

[85] Dolan, J.R. and McKeon, K. (2005) The Reliability of Grazing Rate Estimates from Dilution Experiments: Have We Overestimated Rates of Organic Carbon Consumption by Microzooplankton? Ocean Science, 1, 1-7. http://dx.doi.org/10.5194/os-1-1-2005

[86] Latasa, M. (2014) Comment: A Potential Bias in the Databases of Phytoplankton Growth and Microzooplankton Grazing Rates Because of the Improper Formulation of the Null Hypothesis in Dilution Experiments. Limnology and Oceanography, 59, 1092-1094. http://dx.doi.org/10.4319/lo.2014.59.3.1092

[87] Landry, M. (2014) On Database Biases and Hypothesis Testing with Dilution Experiments: Response to Comment by Latasa. Limnology and Oceanography, 59, 1095-1096. http://dx.doi.org/10.4319/lo.2014.59.3.1095

[88] Newton, K. (2012) Microbial Processes, Structure and Diversity along the Natural Salinity Gradient Present in the Coorong Lagoon, South Australia: A Model for Anthropogenic Impact. Ph.D. Thesis, School of Biological Sciences, Faculty of Sciences and Engineering, Flinders University, Adelaide, 209 p.

[89] Personnic, S., Domaizon, I., Sime-Ngando, T. and Jacquet, S. (2009) Seasonal Variations of Microbial Abundances and Virus-versus Flagellare-Induced Mortality of Picoplankton in Three Peri-Alpine Lakes. Journal of Plankton Research, 31, 1161-1177. http://dx.doi.org/10.1093/plankt/fbp057 
[90] Hewson, I. and Fuhrman, J.A. (2007) Covariation of Viral Parameters with Bacterial Assemblage Richness and Diversity in the Water Column and Sediments. Deep Sea Research Part I: Oceanographic Research Papers, 54, 811-830. http://dx.doi.org/10.1016/j.dsr.2007.02.003

[91] Wilhelm, S.W., Bridgen, S.M. and Suttle, C.A. (2002) A Dilution Technique for the Direct Measurement of Viral Production: A Comparison in Stratified and Tidally Mixed Coastal Waters. Microbial Ecology, 43, 168-173. http://dx.doi.org/10.1007/s00248-001-1021-9

[92] Brussaard, C.P.D. (2004) Viral Control of Phytoplankton Populations-A Review. Journal of Eukaryotic Microbiology, 51, 125-138. http://dx.doi.org/10.1111/j.1550-7408.2004.tb00537.x

[93] Paul, J.H. (2008) Prophages in Marine Bacteria: Dangerous Molecular Time Bombs or the Key to Survival in the Seas? The ISME Journal, 2, 579-589. http://dx.doi.org/10.1038/ismej.2008.35

[94] Payet, J.P. and Suttle, C.A. (2013) To Kill or Not to Kill: The Balance between Lytic and Lysogenic Viral Infection Is Driven by Trophic Status. Limnology and Oceanography, 58, 465-474.

[95] Gonzalez, J.M. and Suttle, C.A. (1993) Grazing by Marine Nanoflagellate on Viruses and Virus-Sized Particles: Ingestion and Digestion. Marine Ecology Progress Series, 94, 1-10. http://dx.doi.org/10.3354/meps094001 
Scientific Research Publishing (SCIRP) is one of the largest Open Access journal publishers. It is currently publishing more than 200 open access, online, peer-reviewed journals covering a wide range of academic disciplines. SCIRP serves the worldwide academic communities and contributes to the progress and application of science with its publication.

Other selected journals from SCIRP are listed as below. Submit your manuscript to us via either submit@scirp.org or Online Submission Portal.
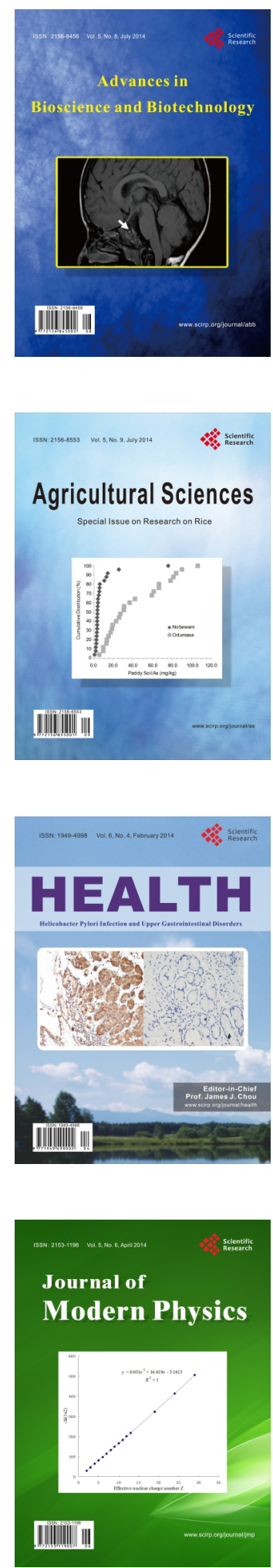
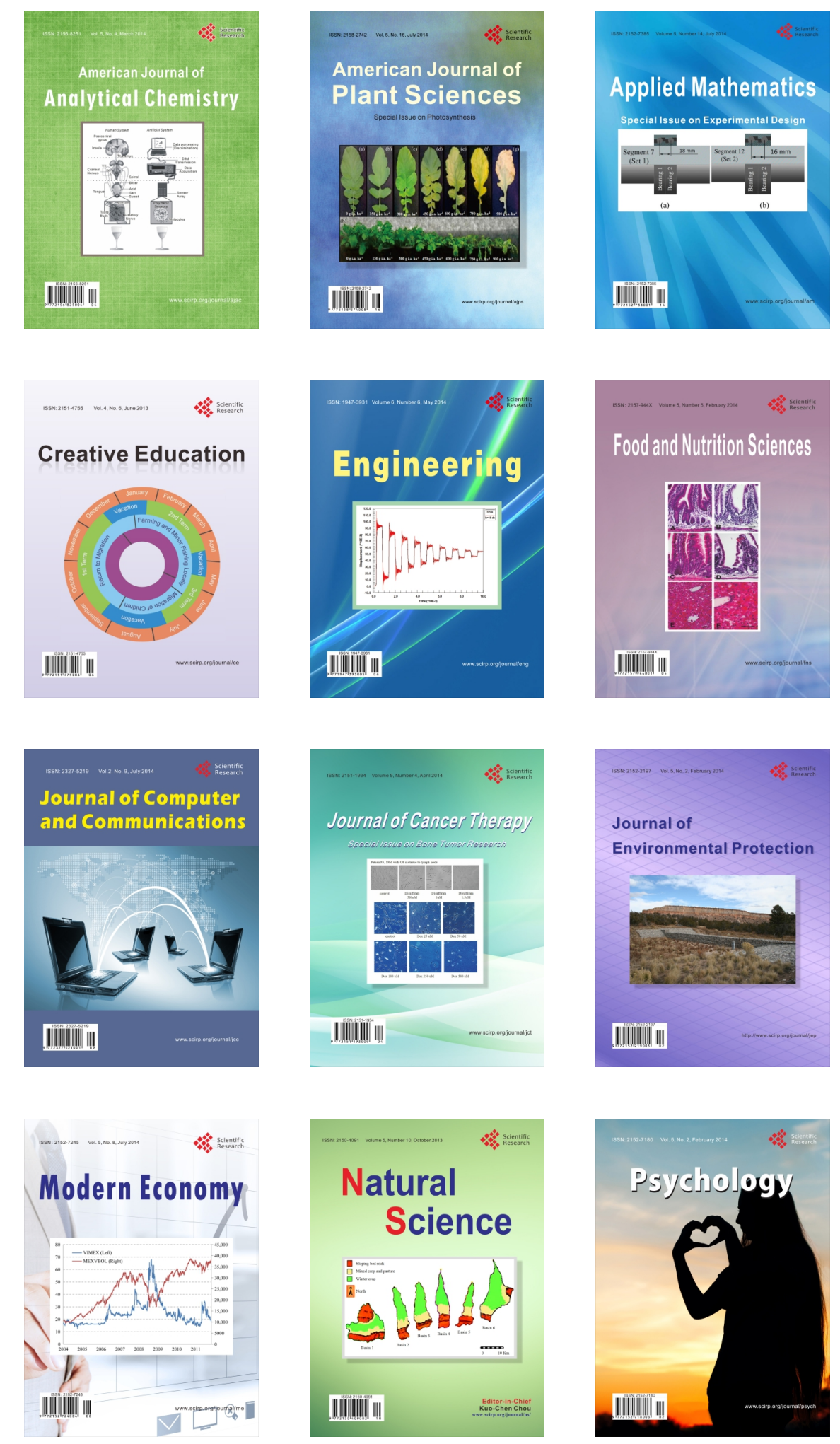